\title{
Will EU Biofuel Policies affect Global Agricultural Markets?
}

Banse, M., H. van Meijl, A. Tabeau, and G. Woltjer

Working Paper, Agricultural Economics Research Institute (LEI), Wageningen UR, The Hague

\begin{abstract}
:
This paper assesses the global and sectoral implications of the European Union Biofuels Directive (BFD) in a multi-region computable general equilibrium framework with endogenous determination of land supply. The results show that, without mandatory blending policies or subsidies to stimulate the use of biofuel crops in the petroleum sector, the targets of the BFD will not be met in 2010 and 2020. With a mandatory blending policy, the enhanced demand for biofuel crops has a strong impact on agriculture at the global and European levels. The additional demand from the energy sector leads to an increase in global land use and, ultimately, a decrease in biodiversity. The development, on the other hand, might slow or reverse the long-term process of declining real agricultural prices. Moreover, assuming a further liberalization of the European agricultural market imports of biofuels are expected to increase to more than $50 \%$ of the total biofuel demand in Europe.
\end{abstract}




\section{Preface}

This paper assesses the global and sectoral implications of the European Union Biofuels Directive (BFD) in a multi-region computable general equilibrium framework with endogenous determination of land supply. The results show that, without mandatory blending policies or subsidies to stimulate the use of biofuel crops in the petroleum sector, the targets of the BFD will not be met in 2010 and 2020. With a mandatory blending policy, the enhanced demand for biofuel crops has a strong impact on agriculture at the global and European levels. The additional demand from the energy sector leads to an increase in global land use and, ultimately, a decrease in biodiversity. The development, on the other hand, might slow or reverse the long-term process of declining real agricultural prices. Moreover, assuming a further liberalization of the European agricultural market imports of biofuels are expected to increase to more than $50 \%$ of the total biofuel demand in Europe.

This work builds forward on the methodlogy developed in the EUruralis project financed by the Dutch Ministry of Agriculture, Nature and Food Quality. In the EUruralis project the GTAP model is extended with first generation biofuels and land markets (Rienks, 2008, Eickhout and Prins 2008). Two methodological improvements which are essential to assess the impact of biofuels and biofuel policies. In this paper we assess the impact of the EU biofuel directive, in another LEI working paper that will appear soon, we assess the the global and sectoral implications of policy initiatives in different countries or regions (e.g. the U.S., the EU, Canada, South Africa or Japan) to enhance bioenergy demand and production. 


\section{Introduction}

World-wide production of biofuels is growing rapidly. From 2001 to 2007, world production of ethanol tripled from 20 billion liters to 50 billion liters (F.O. Licht, 2007), and world biodiesel production grew from 0.8 billion liters to almost 4 billion liters. The production of biodiesel in Europe is growing more rapidly than the production of ethanol, with a current level of more than 5.5 million tonnes of biodiesel and only 2.0 million tones of ethanol. Almost half of the EU biodiesel is produced in Germany, where it is stimulated by tax exemptions.

Figure 1: Biodiesel and bioethanol production in selected regions of the EU, in mio. t, 2003 to 2007

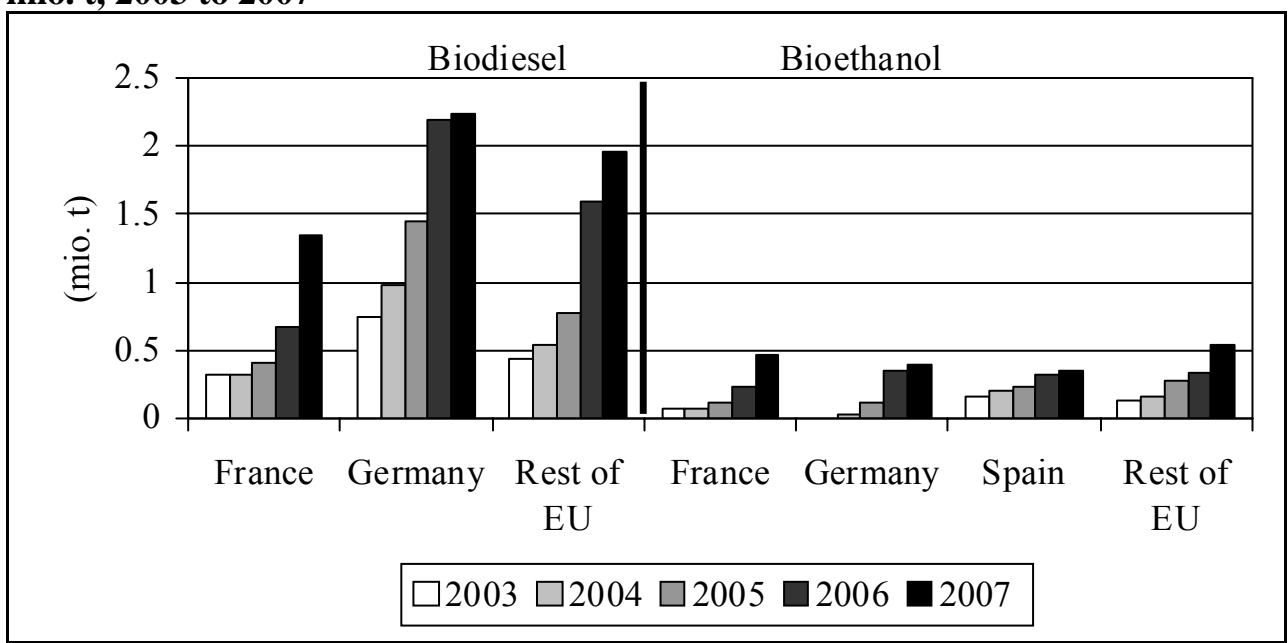

Source: Data derived from F.O. Licht (2007).

In the European Union in 2004, only about $0.4 \%$ of EU cereal and $0.8 \%$ of EU sugar beet production was used for bioethanol, while more than $20 \%$ of oilseed was processed into biodiesel. The annual growth rate between 2005 and 2007 was 53\% and $44 \%$ for bioethanol and biodiesel, respectively (F.O. Licht, 2007).

The initiation of biofuels production was a response to the high oil prices of the 1970s, which were due to supply restrictions by the Organization of the Petroleum Exporting Countries (OPEC) cartel (Figure 2). High oil prices encouraged innovations that saved oil or replaced oil with cheaper or more reliable substitutes, such as biofuels, and world bioethanol production reached approximately 15 billion liters in 1985. In the early 1980s, oil prices returned to their original level and remained constant until the beginning of the new millennium. The level of biofuel production, however, did not decline but was stable, increasing only marginally after 1985 . The recent increase in the price of oil, in conjunction with environmental concerns, led to the recent biofuel boom. The only mature, integrated biofuel market in practice is Brazil's cane-based ethanol market. In this ethanol/electricity cogeneration system, 
sugar cane is a competitive energy provider at crude oil prices around USD \$35 per barrel (Schmidhuber, 2006). The US corn-based ethanol market is also increasingly integrated, however, the infrastructure for transporting the ethanol and related byproducts is still evolving (Tyner et al., 2008).

Figure 2: World fuel ethanol production and crude oil prices, 1970 to 2007

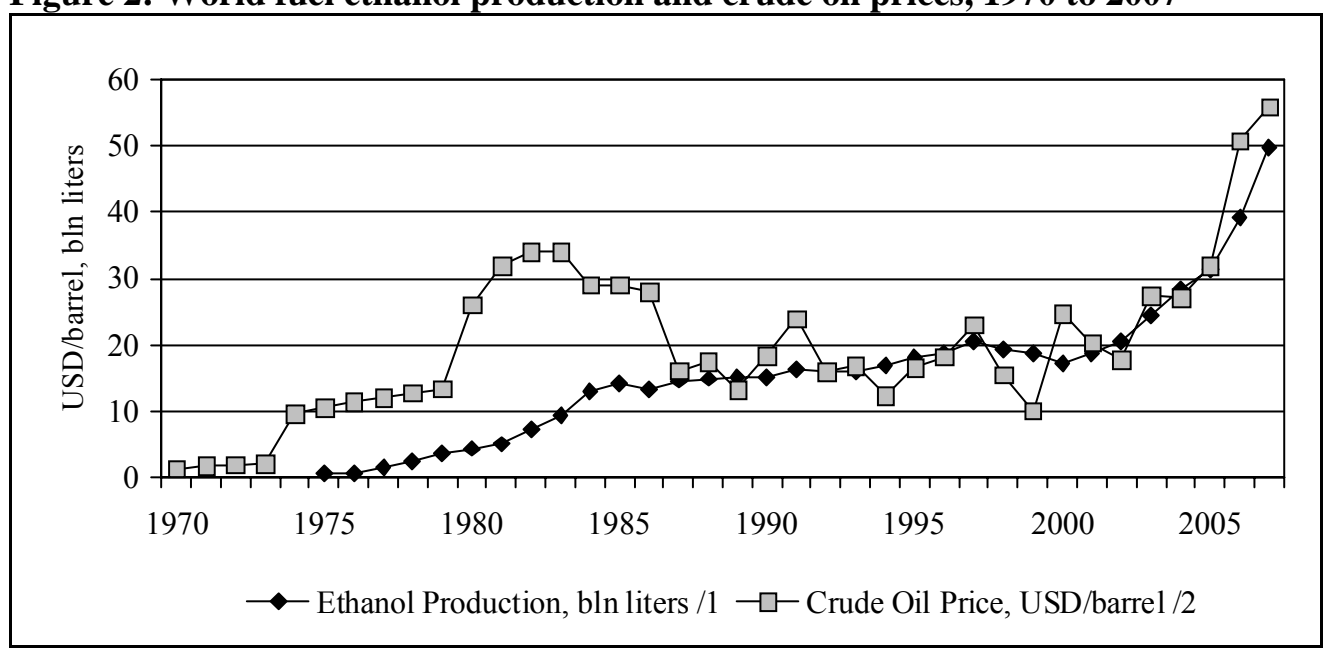

/1 F.O. Licht (2007).

12 Nominal prices. Saudi-Arabian Light- $34^{\circ}$ API.

Source: http://www.eia.doe.gov/emeu/aer/txt/ptb1107.html (17.07.2007)

The driver for biofuel production in the EU, the United States, and Canada is mainly political, including tax exemptions, investment subsidies, and obligatory blending of biofuels with fuels derived from mineral oil. For the United State the replacement of ethanol as a gasoline oxygenate for highly toxic MTBE (methyl tertiary butyl ether) tended to trade at a premium price even above its value of energy. As the current supply of ethanol exceeds the amount needed to replace MTBE the oxygenate premium dropped sharply and US ethanol markets became more vulnerable (Birur et al., 2007).

High energy prices further enhance biofuel production and consumption in other countries and regions. Arguments for biofuel promoting policies include, but are not limited to, reduction of greenhouse gas emissions, diversification of sources of energy, improvement of energy security and a decreased dependency on unstable oil suppliers, and benefits to agriculture and rural areas.

Until very recently, biofuels were produced by processing agricultural crops with available technologies. These 'first-generation biofuels' can be used in low percentage blends with conventional fuels in most vehicles and can be distributed through the existing fuel infrastructure. However, the transportation of pure ethanol to the refineries requires some investments due to the fact that pure ethanol cannot be transported by current tankers (Tyner et al., 2008). Advanced conversion technologies are needed for a second generation of biofuels. The second generation will use a wider range of biomass resources-agriculture, forestry, and waste materials-and promises to achieve higher reductions in greenhouse gas emissions and the cost of fuel production (Smeets et al., 2006; Hoogwijk et al., 2005). 
Given current policy developments and the availability of only first generation biofuels, increased biofuel production due to 'pure' market forces and/or 'policy' might have significant impacts on agricultural markets, including world prices, production, trade flows, and land use. Linkages between food and energy production include the competition for land and other production inputs, while an increasing supply of byproducts of biofuel production, such as oil cake and gluten feed, affects animal production. Furthermore, a biofuel boom raises concerns about the impacts of potential increases in food prices on low income populations as well as the possibility of biodiversity loss due to increased use of land. These implications are poorly understood. This article assesses the global and sectoral implications of the EU Directive on the Promotion of Use of Biofuels (European Commission, 2003) in a multi-region, computable general equilibrium framework. The EU Biofuels Directive (BFD) calls for the EU member states to ensure that biofuels and other renewable fuels attain a minimum share of total transport fuel consumed, which is responsible for almost $25 \%$ of all greenhouse gas emissions in the EU. This share (measured in terms of energy content) should be $5.75 \%$ by the end of 2010 and $10 \%$ by the end of 2020. These goals are not yet mandatory, but this will change for the 2020-target when the recent proposal of the European Commission will be approved by European Parliament and Member States (European Commission, 2008). However, most of the EU member states are far from reaching the target of $5.75 \%$ in 2010 . Table 1 illustrates the current situation: The average use of biofuels in transport at the EU25 level was $1 \%$ in 2005 . The endogenous growth is expected to persist as the price of fossil fuels continues to rise and changing the relative prices in favor of biofuels. This shift in relative prices could also contribute to an increase in profitability of biofuel crops to be used as inputs in fuel production. However, the question of whether the objective can be reached in 2010 or in 2020 remains.

As in the EU, the main drivers for increased biofuel demand in the United States are high energy prices and incentives provided by the Energy Policy Act of 2005 (EPACT05). The EPACT05 requires a minimum of 7.5 billion gallons (approximately 28.7 billion litres) of renewable fuels (ethanol and biodiesel) to be used in the nation's motor fuel by 2012. Most industry and agriculture experts (Tokgozet et al., 2007) project that ethanol production will top out around 57 billion litres by 2012 which is equivalent to $10 \%$ of projected gasoline consumption by volume or $7 \%$ by energy content (US Energy Information Administration, 2008). Apart from the EU and the US, other countries such as Canada, Brazil, Australia, India, and China also have implemented targets for biofuels volumes and market shares. With a focus on the impact of the European BFD on production, land use, and trade, this article contributes to the current discussion around the growing competition between agricultural products and land used for food, feed, and fuel purposes. 
Table 1: Progress in the use of biofuels in the member states, 2003 to 2005

\begin{tabular}{|l|cc|c|}
\hline & 2003 & $\begin{array}{c}2004 \\
\text { Member State } \\
\text { Biofuel share }\end{array}$ & $\begin{array}{c}2005 \\
\text { National } \\
\text { Indicative } \\
\text { Target }\end{array}$ \\
\hline Austria & 0.06 & 0.06 & 2.50 \\
Belgium & 0.00 & 0.00 & 2.00 \\
Cyprus & 0.00 & 0.00 & 1.00 \\
Czech Republic & 1.09 & 1.00 & $3.70^{1}$ \\
Denmark & 0.00 & 0.00 & 0.10 \\
Estonia & 0.00 & 0.00 & 2.00 \\
Finland & 0.11 & 0.11 & 0.10 \\
France & 0.67 & 0.67 & 2.00 \\
Germany & 1.21 & 1.72 & 2.00 \\
Greece & 0.00 & 0.00 & 0.70 \\
Hungary & 0.00 & 0.00 & 0.60 \\
Ireland & 0.00 & 0.00 & 0.06 \\
Italy & 0.50 & 0.50 & 1.00 \\
Latvia & 0.22 & 0.07 & 2.00 \\
Lithuania & 0.00 & 0.02 & 2.00 \\
Luxembourg & 0.00 & 0.02 & 0.00 \\
Malta & 0.02 & 0.10 & 0.30 \\
The Netherlands & 0.03 & 0.01 & $2.00^{2}$ \\
Poland & 0.49 & 0.30 & 0.50 \\
Portugal & 0.00 & 0.00 & 2.00 \\
Slovakia & 0.14 & 0.15 & 2.00 \\
Slovenia & 0.00 & 0.06 & 0.65 \\
Spain & 0.35 & 0.38 & 2.00 \\
Sweden & 1.32 & 2.28 & 3.00 \\
UK & 0.03 & 0.04 & 0.19 \\
EU25 & 0.50 & 0.70 & 1.40 \\
\hline 2006; ${ }^{2}$ Es & & &
\end{tabular}

2006; ${ }^{2}$ Estimate.

Source: European Commission (2007a); Biofuels Progress Report

The economic literature on the impact of biofuels on agricultural markets is scarce, as the biofuel boom is quite recent; Rajagopal and Zilberman (2007) provide a comprehensive survey. Rajagopal and Zilberman (2007) conclude that the current literature is lacking in many respects. These economic models do not capture the dynamic interactions between agricultural and energy markets that will be important in explaining the timing of adoption and diffusion of biofuels, many models do not use oil prices explicitly but only model mandates, and they lack the analysis of international trade aspects of biofuels.

Rajagopal and Zilberman (2007) also state that 'biofuels affect not only farmers, but also affect agro-industries, the well-being of consumers, balance of trade, and the government budget. Understanding the impacts of biofuels on the overall economy requires a modeling framework that accounts for all the feedback mechanisms between biofuels and other markets. The technique that would allow for assessment of 
such effects is a computable general equilibrium (CGE) analysis (Sadoulet and de Janvry, 1995)'.

In this article a general equilibrium approach is used, as energy demand and energy or climate change policies might become crucial determinants of agricultural markets. By using a global, multi-region, multi-sector model, this article seeks to increase the understanding of international trade aspects of biofuels and biofuel policies. In this first attempt, we focus on first generation biofuels only. In addition to the extensions directly related to modeling biofuels, some key characteristics of related markets have been included. A distinguishing feature of our method is the introduction of a land supply curve to include the process of land conversion and land abandonment endogenously (Meijl et al., 2006; Eickhout et al., forthcoming). In their overview article on land use and CGE models Hertel, Rose, and Tol (forthcoming) state: 'The beauty of this [the land supply curve presented by Meijl et al., 2006)] approach lies in the way they build up this supply curve. In particular they capitalize on detailed productivity information available from the IMAGE database.' Furthermore, agricultural labor and capital markets are segmented from factor markets in the rest of the economy.

This article includes four additional sections. Section 2 describes the methodological improvements of the modeling tools as applied in this analysis. The analysed scenarios are introduced in Section 3. Section 4 provides the scenario results of implementing the EU Biofuel Directive and of higher oil prices; this section also offers sensitivity analyses with regard to key model parameters such as the elasticity of substitution between biofuels and fossil fuels and the Armington trade elasticities. Finally, Section 5 summarizes the outcome and results of this paper. 


\section{Modeling of biofuels}

Conform recommendations by Rajagopal and Zilberman (2007) a computable general equilibrium (CGE) model is applied here. So far, many analyses have been done with partial equilibrium models. This approach has been to extend existing models of the agricultural sector by incorporating the demand for biofuels in the form of an exogenous increase in demand for feedstock (e.g., maize, sugar cane, wheat, sugar beet, oilseeds, etcetera) to determine the changes in long-run equilibrium prices and the implications for welfare (OECD, 2006; European Commission, 2007b; Nowicki et al., 2007). A first category of CGE studies analyzed the impact of biofuel and carbon targets on the national economy (Dixon et al., 2007; McDonald et al., 2006; Reilly and Paltsev, 2007), and a second emphasized international trade (Elobeid \& Tokgoz, 2006; Gohin and Moschini, 2007; Birur et al., 2007). Rajagopal and Zilberman (2007) identify the need for a better understanding of the dynamics and international trade aspects of biofuels. The existing studies treat land exogenously, whereas economic (competitiveness and trade) and environmental (especially biodiversity) impacts are related to land use. Therefore, our methodological improvements focus on the integration of the energy and land markets, with special attention to land-use change. This section describes the methodological improvements that are crucial for modeling biofuels in a global general equilibrium model. First, we introduce the standard general equilibrium model (including the data) that is used as a starting point. Second, the extensions of the energy markets necessary to model biofuel demand are discussed, and third, improvements to the modeling of crucial factor markets are discussed with an emphasis on land markets. Since the 2001 Global Trade Analysis Project (GTAP) database does not fully account for biofuel use and its rapid development in the last five years, the original data has been adjusted. This section concludes with a description of the adjustments to the model's data base.

\section{Standard GTAP model features}

The implementation of biofuels builds on a modified version of the GTAP multisector multi-region CGE model (Hertel, 1997). This multi-region model allows the capture of inter-country effects, since the BFD influences demand and supply, and therefore prices, in world markets and hence will affect trade flows, production, and GDP. The multi-sector dimension makes it possible to study the link between energy, transport, and agricultural markets.

In the standard GTAP model each single region is modeled along relatively standard lines of multi-sector CGE models. All sectors are producing under constant returns to scale, and perfect competition on factor markets and output markets is assumed. Firms combine intermediate inputs and primary factors (i.e., natural resources, labor, and capital). Intermediate inputs are used in fixed proportions but are constant elasticity of substitution (CES) composites of domestic and foreign components. In addition, the foreign component is differentiated by region of origin (Armington assumption), which permits the modeling of bilateral (intra-industry) trade flows, depending on the ease of substitution between products from different regions. Primary factors are combined according to a CES function. Regional endowments of natural resources, 
labor, and capital are fixed. Labor and capital are perfectly mobile across domestic sectors. Agricultural land, on the other hand, is imperfectly mobile across alternative agricultural uses, hence sustaining rent differentials. Each region is equipped with one regional household that distributes income across savings and consumption expenditures according to fixed budget shares. Consumption expenditures are allocated across commodities according to a non-homothetic Constant Difference Elasticity of substitution (CDE) expenditure function.

\section{GTAP data used}

Version 6 of the GTAP data for simulation experiments was used. The GTAP database contains detailed bilateral trade, transport, and protection data characterizing economic linkages among regions that are connected to individual country inputoutput databases, which account for intersectoral linkages. All monetary values of the data are in USD millions, and 2001 is the base year for version 6. This version of the database divides the world into 88 regions. An additional interesting feature of version 6 is the distinction of the 25 individual EU member states. The database distinguishes 57 sectors in each of the regions. That is, for each of the 88 regions there are inputoutput tables with 57 sectors that depict the backward and forward linkages between activities. The database provides significant detail on agriculture, with 14 primary agricultural sectors and seven agricultural processing sectors (i.e. dairy, meat products, and further processing sectors).

The social accounting data were aggregated to 37 regions and 23 sectors (Annex Tables A1 and A2, respectively). The sectoral aggregation distinguishes agricultural sectors that can be used for producing biofuels (e.g., grains, wheat, oilseeds, sugar cane, sugar beet), and are important from a land use perspective, and energy sectors that demand biofuels (e.g., crude oil, petroleum, gas, coal, and electricity). The regional aggregation includes all EU15 countries (with Belgium and Luxembourg as one region) and all EU12 countries (with the Baltic countries aggregated to one region, Malta and Cyprus as one region, and Bulgaria and Romania as one region), as well as the most important countries and regions outside the EU from an agricultural production and demand point of view (i.e., Brazil, NAFTA, East Asia and the Rest of Asia, and three regions within Africa).

\section{Energy markets}

The model is extended through the introduction of energy substitution into production by allowing energy and capital to be either substitutes or complements (GTAP-E; Burniaux and Truong, 2002). Compared to the standard presentation of production technology, the GTAP-E model aggregates all energy-related inputs for the petrol sector-such as crude oil, gas, electricity, coal, and petrol products-in the nested structure under the value added side. At the highest level the energy-related inputs and the capital inputs are modeled as an aggregated 'capital-energy' composite (Figure 3). 
Figure 3: Capital-energy composite in GTAP-E

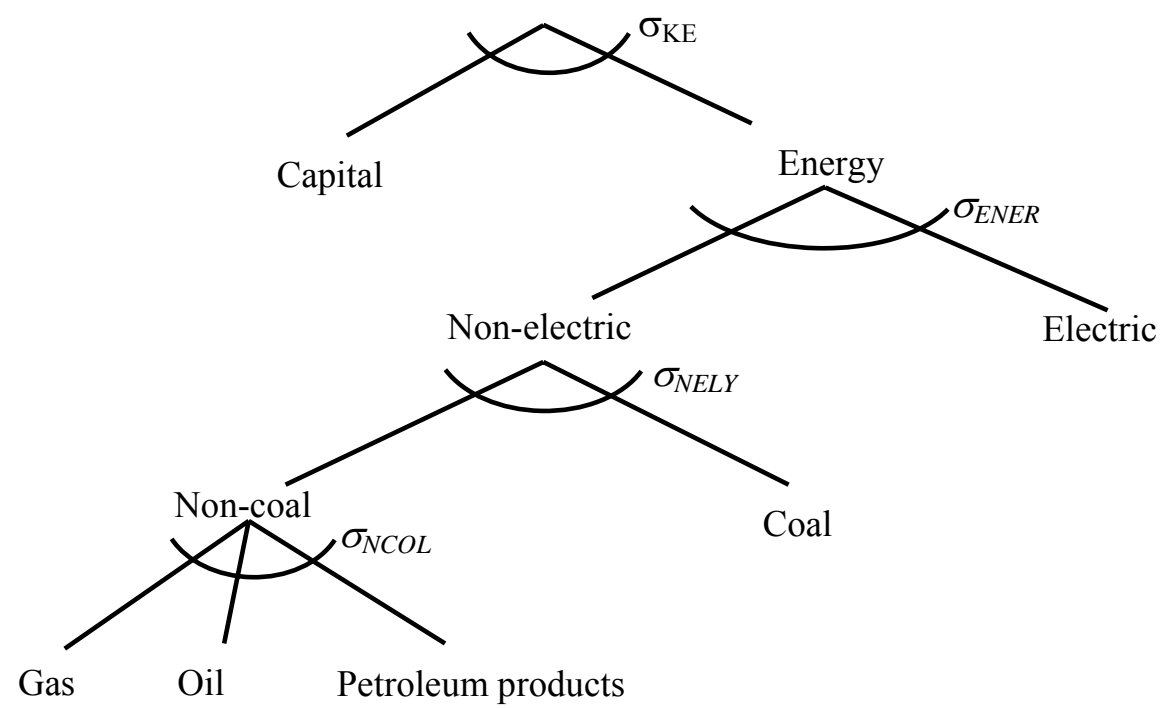

To introduce the demand for biofuels, the nested CES function of the GTAP-E model has been adjusted and extended to model the substitution between different categories of oil (oil from biofuel crops and crude oil), ethanol, and petroleum products in the value added nest of the petroleum sector. The model presents the fuel production at the level of non-coal inputs differently compared to the approach applied under the GTAP-E model (compare Figure 3 and 4). The non-coal aggregate is modeled the following way: 1) the non-coal aggregate consists of two sub-aggregates, fuel and gas; 2) fuel combines vegetable oil, oil, petroleum products, and ethanol; and 3) ethanol is made out of sugar beet/sugar cane and cereals. ${ }^{1}$

\footnotetext{
${ }^{1}$ Ethanol is not modeled as a product for final demand but only as an aggregated composite input in the petrol industry.
} 
Figure 4: Input structure in the petroleum sector

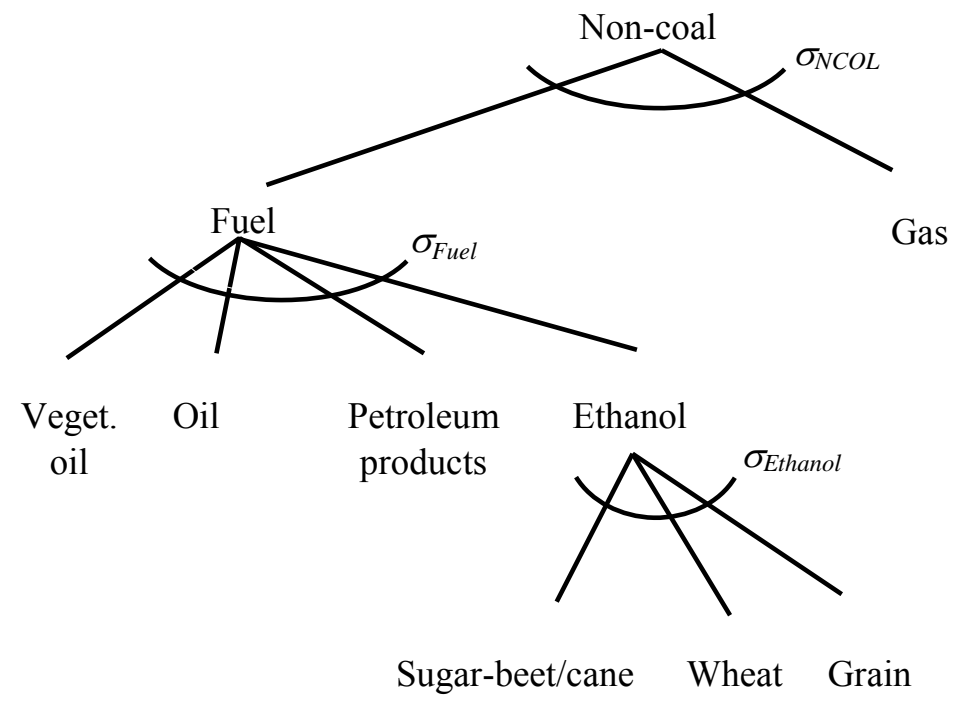

This approach models an energy sector where industry's demand of intermediates strongly depends on the cross-price relation of fossil energy and biofuel-based energy. Therefore, the output prices of the petrol industry will be, among other things, a function of fossil energy and bio-energy prices. The nested CES structure implies that necessary variables of the demand for biofuels are the relative price developments of crude oil versus the development of agricultural prices. Also important is the initial share of biofuels in the production of fuel. A higher share implies a lower elasticity and a larger impact on the oil markets. Finally, the values of the various substitution elasticities ( $\sigma_{\text {Fuel }}$ and $\left.\sigma_{\text {Ethanol }}\right)$ are crucial. These represent the degree of substitutability between crude oil and biofuel crops. The values of the elasticity of substitution are taken from Birur et al., (2007), who-based on a historical simulation of the period 2001 to 2006-obtained a value of the elasticity of substitution of 3.0 for the US, 2.75 for the EU, and 1.0 for Brazil. These values are also applied for this analysis for the years 2001 to 2010 , and a $50 \%$ higher value is used for the years 2010 to 2020 , as economic theory assumes that long run elasticities are higher than short run elasticities as more fixed factors become flexible (Varian, 2003: 391).

In addition, prices for outputs of the petroleum industry will depend on any subsidies/tax exemptions in the respective EU member states that affect the price ratio between fossil energy and bio-energy. Finally, and most importantly for current EU policy, the level of demand for biofuels will be determined by any enforcement of national targets through, for example, mandatory inclusion rates.

A key characteristic of a mandatory blending, such as the EU Biofuel Directive, is that it fixes the share of biofuels in transport fuel. It should be mentioned that this mandatory blending is budget neutral from a government point of view. To achieve this in a CGE model two policies were implemented. First, the biofuel share of transport fuel is specified and made exogenous such that it can be set at a certain target. A subsidy on biofuel inputs is specified endogenously to achieve the necessary 
biofuel share. ${ }^{1}$ The input subsidy is needed to change the relative price ratio between biofuels and crude oil. If the biofuel share is lower than the target, a subsidy on biofuels is introduced to make them more competitive. Second, to implement this incentive instrument as a 'budget-neutral' instrument, it is counter-financed by an end user tax on petrol consumption. A budget equation in which end user tax receipts provide the income and input subsidies provide the spending is introduced into the model. In case of a mandatory blending, it is guaranteed that total spending on these input subsidies is equal to the total revenue of the additional end user taxes on petrol consumption financing the biofuel directive.

The end user tax on petrol is made endogenous to generate the necessary budget to finance the subsidy on biofuel inputs necessary to fulfill the mandatory blending. Due to the end user tax, consumers pay for the mandatory blending as end user prices of blended petrol increase. The higher price results from the use of more expensive biofuel inputs relative to crude oil in the production of fuel.

\section{Factor markets}

To analyze the impact of biofuels, the standard GTAP model has been changed to include several key characteristics of related markets. The functioning of the land market, in particular, is crucial. Birur et al., (2007) use agro-ecological zones (AEZs) in combination with an exogenous land supply, following the methodology outlined in Lee et al. (2005). This article offers an alternative to traditional methods by introducing a new demand structure to reflect the fact that the degree of substitutability of types of land differs among land types (Huang et al., 2004). A distinguishing feature of our method is the introduction of a land supply curve to include the process of land conversion and land abandonment endogenously (Meijl et al., 2006; Eickhout et al., forthcoming).

\section{Allocation of agricultural land}

The standard version of GTAP represents land allocation in a constant elasticity of transformation (CET) structure (left side of Figure 5) assuming that the various types of land use are imperfectly substitutable, but with equal substitutability among all land use types. For this analysis, the land use allocation structure is extended by taking into account the fact that the degree of substitutability differs between types of land (Huang et al., 2004) using the more detailed OECD Policy Evaluation Model (PEM) structure (OECD, 2003) (right part of Figure 5). The extension of the standard GTAP model distinguishes different types of land in a nested three-level CET structure. The model covers several types of land use with different suitability levels for various crops (i.e., cereal grains, oilseeds, sugar cane/sugar beet, and other agricultural uses).

\footnotetext{
${ }^{1}$ In a general equilibrium model the number of endogenous variables must be equal to the number of equations. Therefore, if we make one variable (biofuel share) exogenous, one other variable (input subsidy) must be made endogenous. This is called a closure swap.
} 


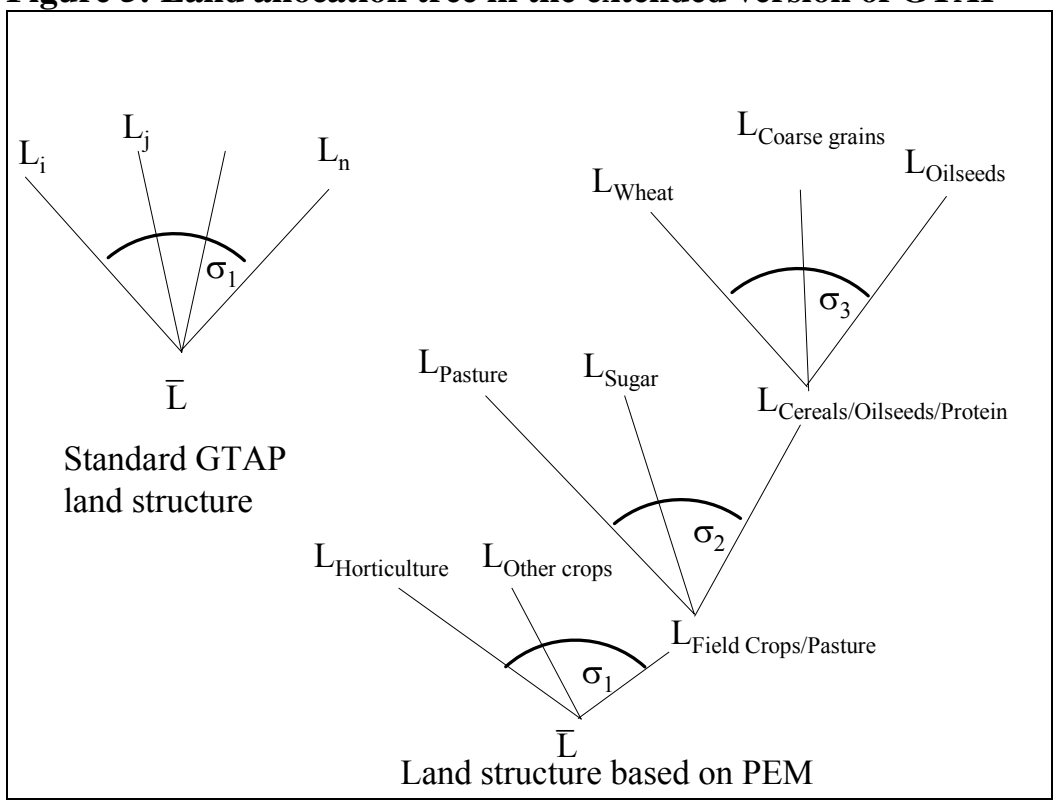

The lower nest assumes a constant elasticity of transformation between 'vegetables, fruit, and nuts' (Horticulture), 'other crops' (e.g., rice, plant-based fibers), and the group of 'Field Crops and Pasture' (FCP). The transformation is governed by the elasticity of transformation, $\sigma_{1}$. The FCP group is itself a CET aggregate of cattle and raw milk (both aggregated under Pasture), 'Sugar,' and the group of 'Cereal, Oilseed, and Protein crops' (COP). Here, the elasticity of transformation is $\sigma_{2}$. Finally, the transformation of land within the upper nest, the COP group (i.e., wheat, coarse grains, and oilseeds), is modeled with an elasticity $\sigma_{3}$. In this way the degree of substitutability of types of land can be varied between the nests. Agronomic features are captured to some extent. In general it is assumed that $\sigma_{3}>\sigma_{2}>\sigma_{1}$, which implies that it is easier to change the allocation of land within the COP group and more difficult to move land out of COP production into, say, vegetables. The values of the elasticities are taken from PEM (OECD, 2003).

\section{The land supply curve}

In the standard GTAP model the total land supply is exogenous. In this extended version, total agricultural land supply is modeled using a land supply curve that specifies the relationship between land supply and a land rental rate in each region (van Meijl et al., 2006). Land supply to agriculture can be adjusted as a result of idling of agricultural land, conversion of non-agricultural land to agriculture, conversion of agricultural land to urban use, and agricultural land abandonment. 


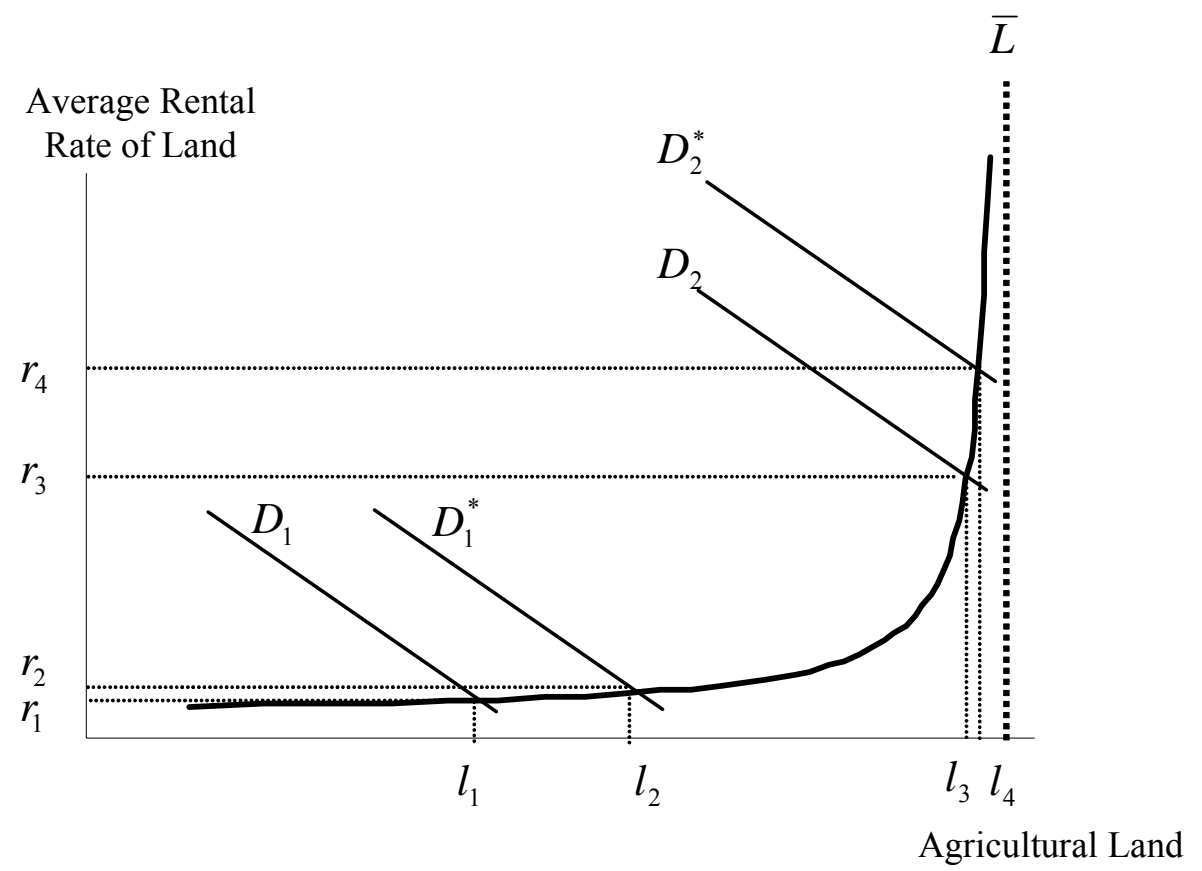

The general idea underlying the land supply curve specification is that the most productive land is the first land put into production. However, the potential for bringing additional land into agricultural production is limited. For land-abundant countries, the gap between potentially available agricultural land $(\bar{L})$ and land used in the agricultural sector is large-the increase in demand for agricultural land (presented as a shift of the land demand curve from $\mathrm{D}_{1}$ to $\mathrm{D}_{1}{ }^{*}$ ) will lead to land conversion to agricultural land (from $l_{1}$ to $l_{2}$ ) and a modest increase in rental rates (from $r_{1}$ to $r_{2}$ ) to compensate for the cost to take this land into production (left part of Figure 6). However, in the case of land-scarce countries where almost all agricultural land is in use, an increase in demand for agricultural land (presented as a shift of the land demand curve from $\mathrm{D}_{2}$ to $\mathrm{D}_{2}{ }^{*}$ ) will lead primarily to a drastic increase of the land rental rates from $r_{3}$ to $r_{4}$ and not to land conversion (from $l_{3}$ to $l_{4}$ ), meaning that land becomes scarce (right part of Figure 6). Therefore, an increase in the demand for land due to increased biofuel demand will lead immediately to higher land and product prices in land-scarce countries (e.g., Japan and Korea, Europe) relative to landabundant countries (e.g., Brazil, Rest of South America, NAFTA) and will influence their competitiveness and the locations where biofuels are produced.

The key problem is the empirical implementation of this land supply curve for all major regions in the world, as land price data are not available on a global scale. Eickhout et al. (2007) use biophysical data from the IMAGE model to approximate the supply curve. For the EU15 countries, more information on land prices is available, and empirical estimates have been used here (Cixous, 2006). 
In addition to these changes to the land market, factor market segmentation has also been introduced for labor and capital between agricultural and non-agricultural markets. If labor is perfectly mobile across domestic sectors, equalized wages throughout the economy for workers with comparable endowments would be observed. This is not supported by evidence. Wage differentials between agriculture and non-agriculture can be sustained in many countries (especially developing countries) through a limitation on labor migration out of agriculture (De Janvry et al., 1991). Returns to assets invested in agriculture also tend to diverge from returns on investment in other activities. Factor market segmentation is introduced by specifying a CET structure that transforms agricultural labor (and capital) into non-agricultural labor (and capital) (Keeney and Hertel, 2005). The elasticities of transformation can be calibrated to fit estimates of the elasticity of labor supply from PEM (OECD, 2003).

Agricultural policies are crucial for the development of biofuels. As this article focuses on the EU Biofuel Directive, some key features of the Common Agricultural Policy have been included, such as agricultural quotas (milk and sugar) implemented as a complementarity problem (Meijl and Tongeren, 2002).

\section{Adjustment of the GTAP 6 database toward biofuels}

Developments in the biofuel sector are extremely rapid. Therefore, the GTAP database has been updated to include recent developments. The calibration of the use of biofuel crops in the model is based mainly on sources published in Licht's (2007) World Ethanol and Biofuel Reports as well as his Interactive Database for Ethanol and Biofuels. Current use of biofuels at the EU member state level is derived from Eurostat and publication of the European Commission (Table 1). For implementing first generation biofuels, the GTAP database has been adjusted for the input demand for grain, sugar, and oilseeds in the petroleum industry. Under the adjustment process, the total intermediate use of these agricultural products at the national level has been kept constant while the input use in non-petroleum sectors has been adjusted in an endogenous procedure to reproduce 2004 biofuels shares in the petroleum sector (corrected for their energy contents). Furthermore, several agricultural data in the standard GTAP database have been adjusted to improve the initial database. Subsidies of the EU Common Agricultural Policy have also been adjusted, including quota rents for sugar and milk, sugar beet use in the production of sugar, oilseed use in the production of vegetable oils and fats, and introduced total agricultural and sectoral land acreages. 


\section{Description of scenarios}

To assess the impact of biofuels and related polices, the 'Global Economy' scenario of the EURURALIS project is used as a reference scenario for this analysis (Wageningen UR and Netherlands Environmental Assessment Agency, 2007). The 'Global Economy' scenario is an elaboration of one of the four emission scenarios of the Intergovernmental Panel on Climate Change (IPCC), as published in its Special Report on Emission Scenarios (SRES) (Nakicenovic et al., 2000) and the Netherlands Bureau of Economic Policy Analysis (CPB) detailed focus on Europe with more regional and sectoral disaggregation (CPB, 2003).

Table 2: Assumptions of reference or 'Global Economy' scenario.

\begin{tabular}{|c|c|}
\hline Trade policies & $\begin{array}{l}\text { Stepwise elimination of all trade barriers. } \\
\text { - 2010: } 25 \% \text { reduction compared with } 2001 \\
\text { - 2020: 50\% reduction compared with } 2010\end{array}$ \\
\hline $\begin{array}{l}\text { Domestic support } \\
\text { in agriculture }\end{array}$ & $\begin{array}{l}\text { CAP reform 2003: full decoupling } \\
\text { - 2010: } 25 \% \text { reduction of domestic support, new EU } \\
\text { member states domestic agricultural support agreed by } \\
\text { EU minus } 25 \% \text { reduction } \\
\text { - 2020: } 50 \% \text { reduction compared with } 2010\end{array}$ \\
\hline Production quotas & 2020: abolished \\
\hline Biofuels & No blending obligations \\
\hline Set aside & $\begin{array}{l}\text { Abolished in EU15 in 2010, never introduced in new member } \\
\text { states }\end{array}$ \\
\hline
\end{tabular}

Under the 'Global Economy' scenario, which elaborates the A1 scenario of the SRES, the World Trade Organization (WTO) negotiations are assumed to have concluded successfully and global trade is assumed to be moving toward full liberalization (Table 2). Technological change is assumed to be high.

In the reference scenario there is a strong increase in GDP per capita across all regions covered in this analysis. However, growth rates differ between regions from $1.7 \%$ per year in Japan and Korea to $6.4 \%$ per year in East Asia (Table A-3 in the annex).

Important driving forces are the demographic, macro-economic, and technological developments and policy assumptions. Demographic and macro-economic assumptions are taken from studies that implement the SRES. The population numbers are taken directly from SRES scenarios (Nakicenovic et al., 2000). In these scenarios the population size and structure are determined by scenario-specific assumptions about three fundamental demographic processes: fertility, mortality, and migration. The global macro-economic development is an important driving force, affecting consumption of all goods. Macro-economic growth (expressed as GDP growth) is differs per scenario and per country. GDP growth and consistent employment and capital growth per scenario are taken from CPB (2003); the growth rates were calculated with the CPB macro-economic Worldscan model. The scenarios 
are constructed through recursive updating of the database for two consecutive time periods (i.e., 2001 to 2010, 2010 to 2020) such that exogenous GDP targets are met and given the exogenous estimates on factor endowments-skilled labor, unskilled labor, capital, and natural resources-and population. The procedure implies that an additional technological change is endogenously determined within the model (see also Hertel et al., 2004). In line with CPB, we assumed common trends for relative sectoral total factor productivity (TFP) growth. CPB assumed that all inputs achieve the same level of technical progress within a sector (i.e., Hicks neutral technical change); however, we deviate from this approach by using additional information on yields from FAO and the IMAGE model.

In the policy scenario, the implementation of the EU Biofuel Directive is applied as an example for a mandatory blending obligation and illustrates the consequences of this biofuel policy on the national and international markets for agri-food products. In this scenario a $5.75 \%$ mandatory blending is applied in 2010 , and a $10 \%$ mandatory blending rate is applied in 2020 in each of the EU member states.

Since the biofuel market is surrounded with uncertainties, two additional scenarios have been calculated with regard to the development of world crude oil prices. Under the scenarios 'Reference, high oil price' and 'BFD, high oil price' the increase in oil price is $70 \%$ higher than in the reference or the BFD scenarios. A sensitivity analysis has been conducted with regard to some crucial model parameters such as the elasticity of substitution between different inputs in the petroleum industry and the Armington elasticities on trade. ${ }^{1}$

\footnotetext{
${ }^{1}$ In these scenarios the substitution elasticities in the petrol industry ( $\sigma_{\text {Fuel }}$ and $\sigma_{\text {Ethanol }}$, see figure 4$)$ and the trade elasticities are increased and decreased by $50 \%$, respectively.
} 


\section{Scenario results}

This chapter section presents the results for the reference, biofuel policy, and oil price scenarios. Note that under the policy scenarios only the mandatory blending obligation within the EU is changed. All other policy instruments remain unchanged compared to the reference scenario. Section 4.3 describes a sensitivity analysis with regard to some important model parameters.

\subsection{Scenario results}

With enhanced biofuel consumption as a result of the EU Biofuel Directives $(5.75 \%$ in 2010 and $10 \%$ in 2020), prices of agricultural products tend to increase. This is especially the case for those products that are directly used as biofuel crops. Under the reference scenario, real world prices for agricultural products tend to decline and conform to their long-term trend (Figure 7). This is caused by an inelastic demand for food in combination with a high level of productivity growth (Schmidhuber, 2007). ${ }^{1}$ Under the BFD scenario, world prices rise relative to the reference scenario. The real price of oilseeds shows an increase of $8 \%$ in contrast to the long-term trend projected in the reference scenario. Compared to the US and Brazil, where ethanol consumption dominates the biofuel sector, EU biofuel is based on bio-diesel, which is reflected by the increase in prices of the bio-based inputs in the production of biofuels. The increase in world prices is less than in some other global studies (i.e., Rosegrant et al., 2007) where oilseed and sugar prices rise $18 \%$ and $10 \%$, respectively.

Figure 7: Change in real world prices, in percent, 2020 relative to 2001

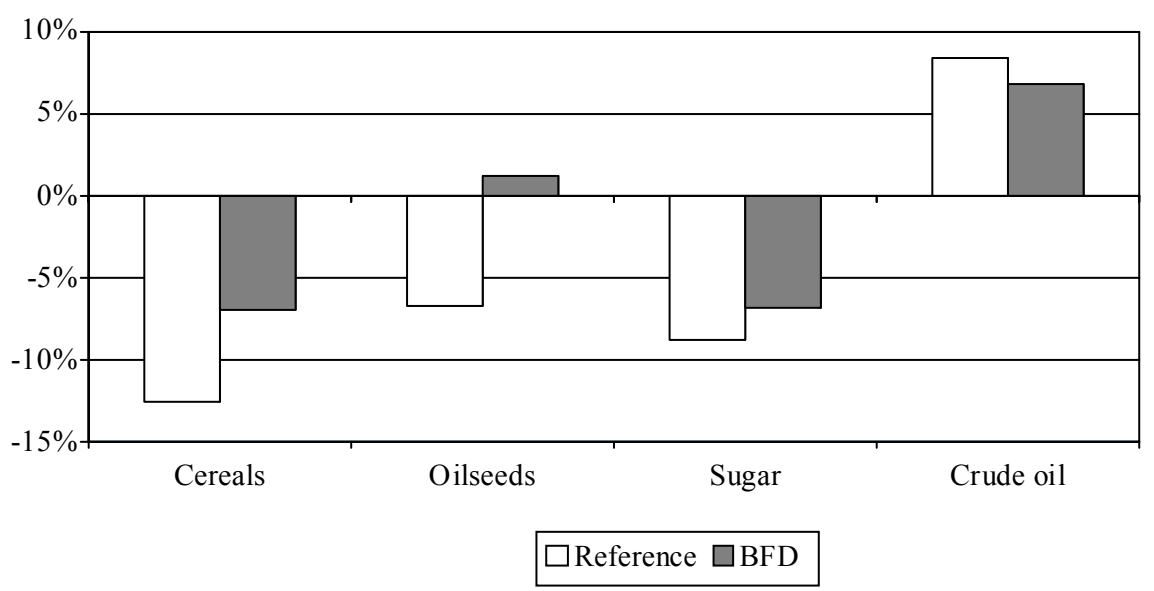

\footnotetext{
${ }^{1}$ The reference scenario of this article is based on the projection of long-term trends on global agriculture and food markets and therefore does not include the current high price development on agrifood markets.
} 
There are several reasons for this difference. First, this paper considers only the impact of the EU Biofuel Directive and not all directives in the world. Second, this paper includes land endogenously, meaning that more land can be taken into production, which suppresses land prices and therefore product prices (Figures 11 and 12 , respectively). The crude oil price declines slightly (1.5\%) as demand for crude oil diminishes due to the introduction of the BFD. Similarly, Dixon et al. (2007) showed a decline in the world crude oil price of $4.5 \%$ due to US biofuel policies.

Even without enforcing the use of biofuel crops through a mandatory blending, the share of biofuels in fuel consumption for transportation purposes increases slightly (Figure 8). This endogenous increase in biofuel production is due to the fact that the ratio between the crude oil price and prices for biofuel crops changes in favor of biofuel crops (Figure 7). Under the reference scenario biofuel shares increase. The highest increase is in the already integrated market of Brazil, where the initial 2001 share of greater than $28 \%$ expands to more than $31 \%$ in 2020 . In Germany and France, the endogenous growth of the biofuel share leads to biofuel consumption for transportation of 3.2\% in Germany and $1.2 \%$ in France in 2010 and a share of $3.8 \%$ in Germany and $1.8 \%$ in France in 2020. These results reveal that without a mandatory blending the $5.75 \%$ and $10 \%$ biofuel targets will not be reached in the EU member states. Even under a scenario with a strong increase in crude oil price the shares of biofuel use in transportation will remain below $10 \%$ in 2020. However, higher oil prices affect biofuel consumption significantly. In Germany, biofuel consumption increases by more than 7\% and more than 5\% in France. The biofuel share in Brazil increases above $38 \%$.

Figure 8: Development of percent share of biofuels in fuel consumption for transportation for selected regions, 2001, 2010, and 2020

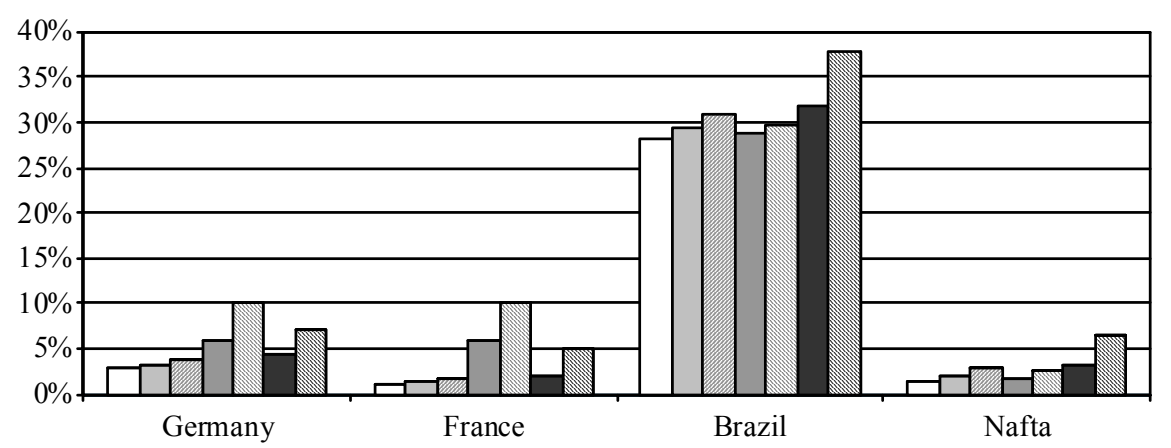

\begin{tabular}{|lll|}
\hline$\square 2001$ & $\square$ Reference, 2010 & $\square$ Reference, 2020 \\
$\square$ BFD, 2010 & $\square$ BFD, 2020 & $\square$ Reference high oil price, 2010 \\
$\square$ Reference high oil price, 2020 & & \\
\hline
\end{tabular}

With a mandatory blending policy, the EU member states fulfill the required targets of $5.75 \%$ in 2010 and $10 \%$ in 2020; however, this occurs at the expense of non-European countries. By meeting the EU targets the share of biofuel use declines in Brazil by $1 \%$ and in NAFTA by $5 \%$. The decline in biofuel consumption in non-European countries is due to the increase in relative prices between biofuel crops and crude oil. The enhanced demand for biofuel crops in the EU under the BFD scenario leads to an 
increase in world prices for these products and, hence, to a decline in the profitability in fuel production compared to crude oil. As the elasticity of substitution between crude oil and biofuels is lower in Brazil than in NAFTA, the decline in use in Brazil is lower than for NAFTA (Section 3). However, the increase in biofuel crop demand in the EU overcompensates for the decline in non-EU countries, and at global level the use of biofuel crops for fuel production increases under the BFD scenario. A good indicator for this development is the decline in crude oil price under the BFD scenario compared with the reference scenario (Figure 7).

Figure 9: Origin of biofuel crops used in the EU-27 (in bill. US\$, real 2001) ${ }^{1}$

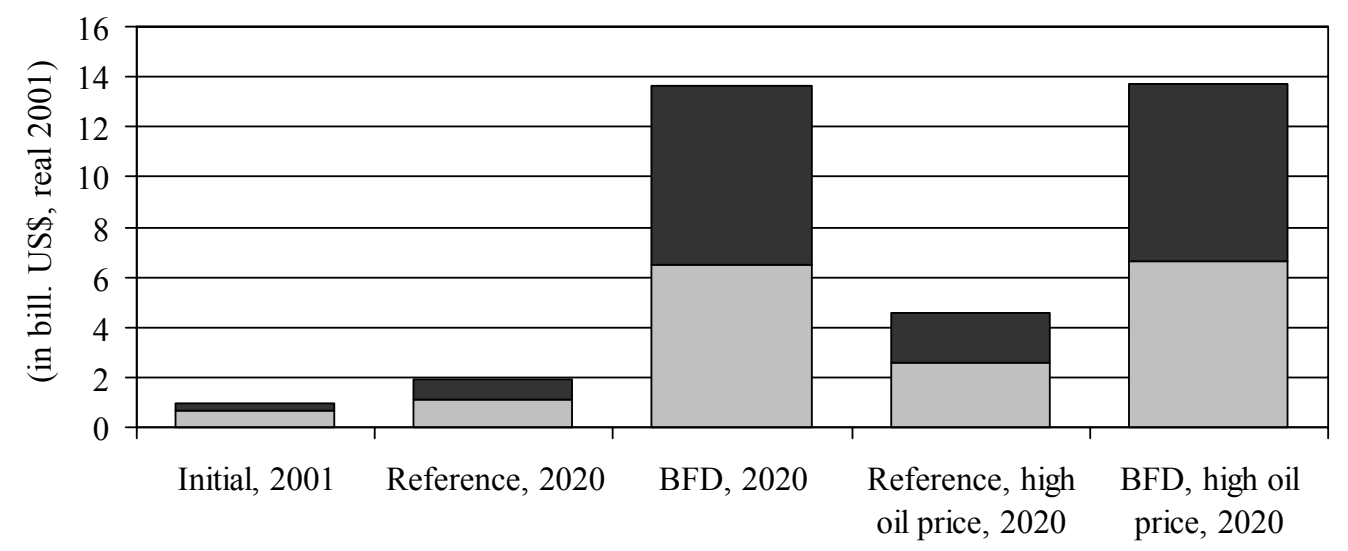

\begin{abstract}
domestic $\square$ imported
${ }^{1}$ Numbers in \% indicate the share of imported biofuel crops in total use of biofuel crops in petrol sector.

To meet the ambitious future targets of the EU Biofuels Directive, large scale production of biofuel crops in Europe will be necessary. In the BFD scenario the demand for biofuel crops used in the petrol sector will be USD \$14 billion (in 2001 dollars) under the minimum blending of $10 \%$ in 2020 (Figure 9). Approximately $47 \%$ of these inputs will be produced domestically, and $53 \%$ of biofuel crops used in the petrol sector will come from imports. In the reference scenario the demand for biofuel crops in 2020 is projected to reach USD \$2 billion with an import share of $42 \%$. Figure 9 shows that the higher the use of biofuels in the EU, the higher the import share, assuming a liberalizing European agricultural market (section 3). As illustrated in Figure 6, the relative land scarcity in Europe can partly explain this growing dependency on biofuel crop imports. An increased demand for biofuel products leads to higher land and product prices relative to land abundant countries, which are often exporters to the EU market (negative price substitution effect).
\end{abstract}

The dependency of the EU on import to meet the BFD target is not clear from the literature (see European Commission, 2007b; von Lampe, 2007; Banse and Grethe, 2008). In the projection published by the EU Commission (2007b), the import share is expected to be approximately $20 \%$ while von Lampe (2007: 235), in absence of modeling international trade, states that a 'European biofuel industry [based] on biodiesel is likely to require substantial additional imports of vegetable oils.' The estimates published by the EU Commission are based on the assumption that second generation biofuel crops will cover $30 \%$ of required inputs in 2020 . It is, however, 
questionable whether this assumption is realistic (see Wiesenthal et al., 2007). Banse and Grethe (2008) show that without second generation biofuel crops the import share of biofuels will be $35 \%$. All three publications are based on partial equilibrium models that take the development of land prices as exogenous. As described above, factor prices-especially land-are crucial (Figure 12).

Figure 10 shows that the EU trade deficit for agricultural commodities used for the production of biofuels will increase under the BFD scenarios. South and Central America as well as other land abundant countries (e.g., NAFTA) will expand their net exports in agricultural products for biofuel production. The availability of land enables these countries to increase their production without drastic increases in land and product prices, whereas this is not possible in land-scarce countries. Contrary to the BFD, a higher oil price leads to lower net exports of biofuel crops in high income countries (e.g., NAFTA) as domestic biofuel demand is sensitive to the oil pricesubstitution elasticity between crude oil and biofuels has a value of three (3.0) whereas it is one (1.0) in South America-and there is less land available. Furthermore, a higher oil price leads to higher net exports in South and Central America and Africa and to higher net imports in the EU.

\section{Figure 10: Balance in biofuel crop trade (in bill. US\$, real 2001)}

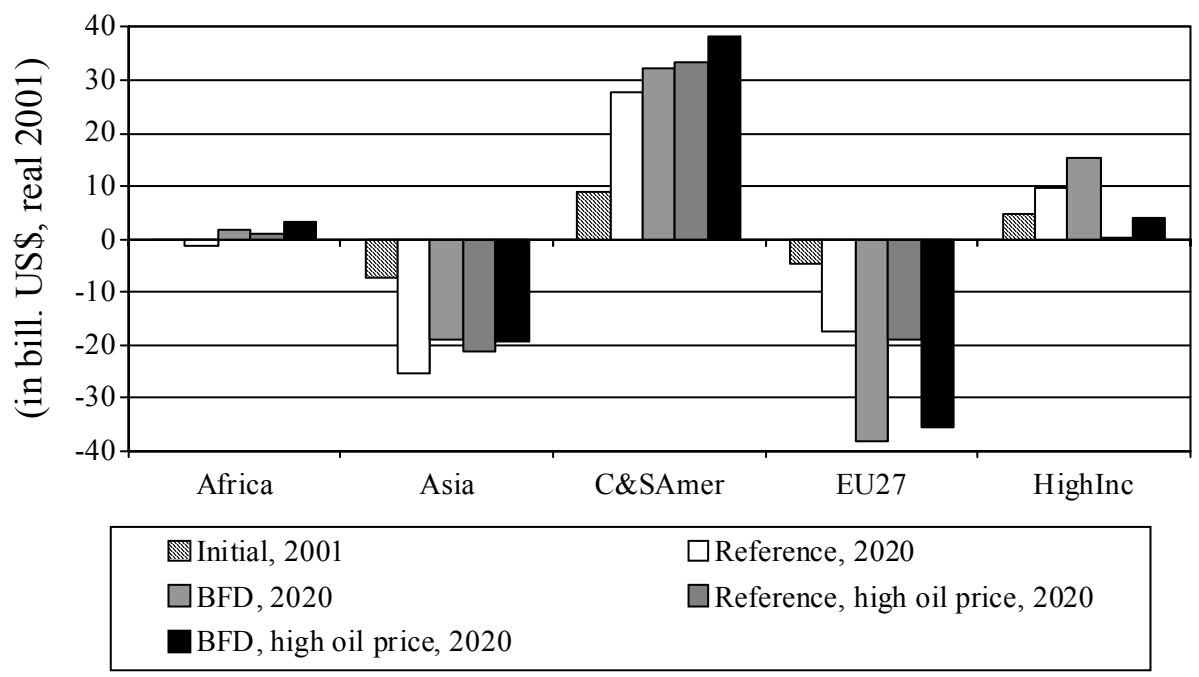

Compared to world income growth, the annual growth rates of agricultural production are quite moderate in the reference scenario. In the EU and in the high income countries (HighInc region), agricultural production is negatively affected by the liberalization that is implemented in the reference scenario. At the aggregated level, total arable production increases in the reference and both policy scenarios. The EU decrease in biofuel crops (i.e., oilseeds, grains, and sugar) in the reference scenario is caused by the huge decline in sugar production due to liberalization (see also Nowicki et al., 2007). In all regions, mandatory blending also leads to an increase in total arable output (Table 3). Comparing the BFD scenario with the reference, the strongest relative increase in agricultural output takes place in the EU, where the increase in demand appears, and in land-abundant South and Central America and NAFTA due to increased exports (Figure 10). 
Table 3: Percent changes in agricultural production, 2020 relative to 2001

\begin{tabular}{l|rrrrrrr|} 
& Africa & Asia & C\&SAmer & EU & HighInc & NAFTA & World \\
\hline Arable Crops & & & & & & & \\
Reference & 68.2 & 46.9 & 51.4 & 14.2 & 18.5 & 39.3 & 36.2 \\
BFD & 68.8 & 47.0 & 56.5 & 17.7 & 19.7 & 41.2 & 37.5 \\
Ref., high oil price & 70.2 & 48.6 & 57.7 & 15.1 & 24.0 & 48.5 & 38.9 \\
BFD, high oil price & 70.8 & 48.6 & 61.6 & 17.4 & 24.9 & 49.9 & 39.9 \\
Biofuel Crops & & & & & & & \\
Reference & 103.3 & 68.0 & 73.1 & -12.2 & 22.5 & 26.8 & 41.0 \\
BFD & 111.3 & 70.0 & 86.1 & 6.4 & 25.4 & 29.8 & 48.6 \\
Ref., high oil price & 112.2 & 79.8 & 95.9 & -4.1 & 36.3 & 41.8 & 53.4 \\
BFD, high oil price & 118.6 & 81.2 & 106.1 & 9.0 & 38.4 & 43.8 & 59.1 \\
Oilseeds & & & & & & & \\
Reference & 91.0 & 61.4 & 66.0 & 5.6 & 56.8 & 58.6 & 55.1 \\
BFD & 102.7 & 63.7 & 84.7 & 41.3 & 65.4 & 67.6 & 66.1 \\
Ref., high oil price & 117.8 & 77.7 & 90.6 & 22.9 & 93.8 & 97.1 & 78.4 \\
BFD, high oil price & 126.5 & 79.1 & 104.5 & 44.1 & 99.1 & 102.6 & 85.7 \\
\hline
\end{tabular}

Table 3 presents the results for changes in oilseed production, which expands significantly under the policy scenarios as EU biofuel is based on bio-diesel. Oilseed production in the EU27 increases from almost $6 \%$ in the reference to $41 \%$ in the BFD scenario. A higher oil price leads to an increase in production of biofuel crops in all regions in the world, especially in South America where both domestic demand (Figure 8) and net exports (Figure 10) increase and in NAFTA where domestic demand is the driving force (Figure 8). Apart from the direct impact of an increase in biofuel demand on prices and production, the changes in agricultural income from agricultural are significant. The EU farm income increases relative to the reference scenario where farm income declined after reduction of income and price support. The positive development in incomes is mainly due to higher agricultural prices.

Figure 11: Change in total agricultural land use, in percent, 2020 relative to 2001

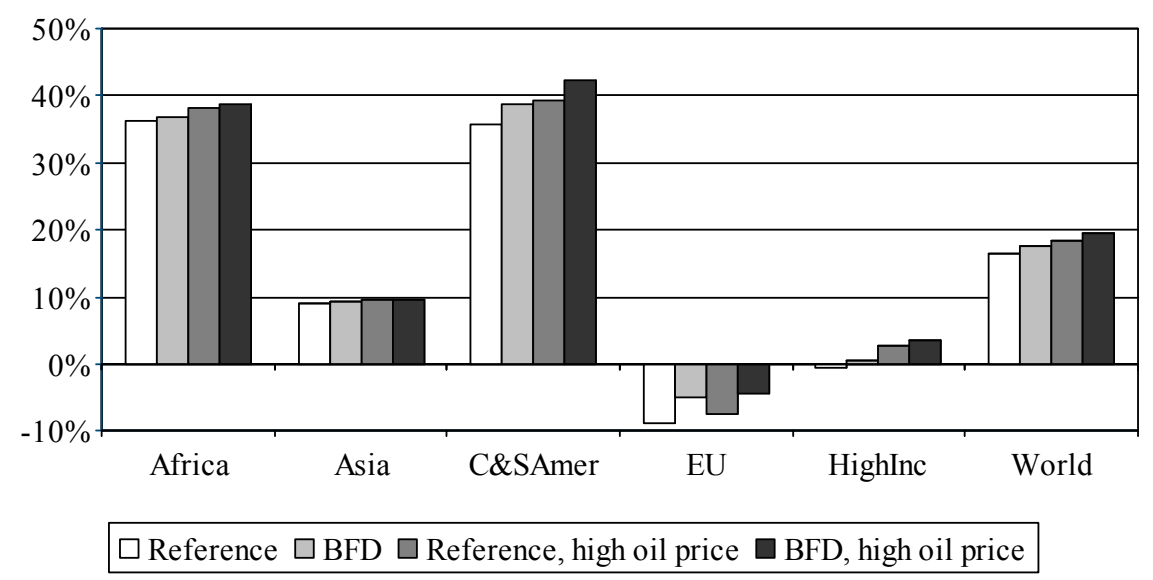

The production developments lead to a similar pattern of land use developments, as land is a key input in production (Figure 11). Next to the demand for land, the 
position of a region on the land supply curve is crucial (Figure 6). Land use increases under the BFD scenario in all regions compared with the reference scenario; therefore, land use also increases at the global level. In the EU, the decline in agricultural land use as a consequence of the liberalization in the reference scenario, is reduced by nearly $50 \%$ under the BFD scenario, This expansion of agricultural land use on a global scale-and especially in land-abundant South America-might indicate a decline in biodiversity as land use is an important driver for biodiversity (see CBD, 2006).

Figure 12: Change in the price for agricultural land 2020, in percent, relative to reference scenario

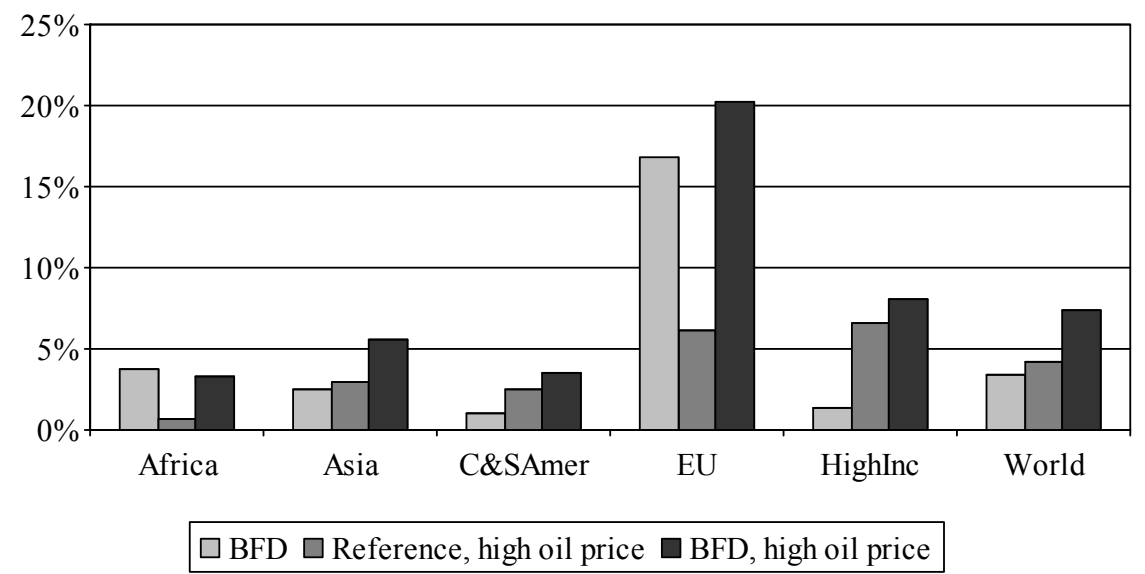

The Biofuel Directive affects land prices at global level. Compared to the reference scenario, land prices are higher: between 1\% in Central and South America and 16\% in the EU. High prices for crude oil lead to an increase in the use of biofuel crops in fuel production and also affect land prices. If high oil prices coincide with the BFD blending target, land prices increase by more than $7 \%$ at the global level and by more than $20 \%$ in the EU. 
Figure 13: Share of agricultural land used for biofuel crops in total agricultural land use, in percent, 2001 and 2020

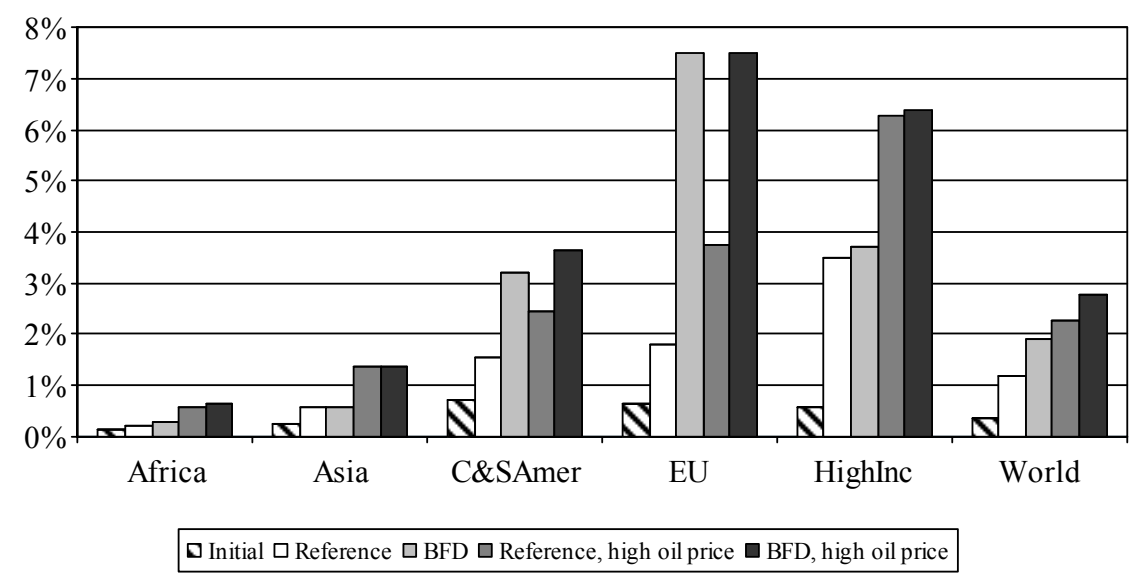

Growing biofuel crop production leads to increased demand for agricultural land used for biofuel cropping. Under the reference scenario, the initial share of land sown with biofuel crops grows from $0.3 \%$ to $1.2 \%$ globally (Figure 13). In 2001, the model's base year, the share of biofuel crop land is the highest in Central and South America $(0.7 \%)$ followed by the European Union $(0.6 \%)$. Under the reference scenario, the share of land used for biofuel crops increases to $1.8 \%$ in the EU and to $1.5 \%$ in Central and South America. At the global level, more than 1.2\% of total agricultural land would be used for biofuel cropping. Under the BFD scenario this picture differs significantly. More than $7 \%$ of agricultural land in the EU would be sown with biofuel crops. The area used for biofuel crops also would expand in Central and South America as well as in the high income countries. A similar effect can be observed if the crude oil price remains high. In the high income countries the impact of a high oil price is more important than the BFD, as the domestic use (Figure 8) and production (Table 3) increase more under this scenario. Therefore, at the global level, land used for biofuel cropping is more affected by high oil prices than by the European BFD. However, at the regional level important changes in land use because of European biofuel policies are seen in the EU itself, but also in Central and South America as main exporting region for Europe.

As outlined above, the targets set in the biofuel scenarios are (endogenously) enforced through a mandatory blending requirement on the use of biofuel crops as intermediates in the petroleum sector. Overall, due to this blending requirement petrol prices in the EU increase approximately $2 \%$ to meet the $5.75 \%$ mandatory blending obligations in 2010 and about $6 \%$ to meet the $10 \%$ BFD target in 2020 as feedstock is more expensive than crude oil. The internal subsidies on biofuel crops in the petroleum sector, which are required to meet the targets by making feedstock competitive with crude oil, are high and range from $30 \%$ in Sweden to almost $60 \%$ in the UK in 2020. The level of the subsidies is determined by the initial biofuel share and the availability of feedstock to make biofuels. The subsidies required to meet the targets are very high, indicating that fulfilling the targets is a challenge for the EU countries. These subsidies indicate the difficulties most EU member states will face in 
attempting to meet the targets of the BFD. The difficulties might be surpassed by making biofuels more competitive due to higher levels of technical change to produce biofuels. Higher yields and especially more efficient conversion technologies are needed to make biofuels competitive (Dale, 2003).

Under high oil prices the subsidies required to implement the biofuel target will drop significantly. In Sweden-the current front-runner in terms of biofuel use in the EUthe subsidy is almost zero. The macroeconomic costs of introducing the mandatory blending in terms of a lower GDP per capita growth are limited in the EU countries.

\subsection{Sensitivity analyses}

Because the biofuel market is surrounded by uncertainties, we prepared sensitivity scenarios with regard to two of the main parameters. Section 3 pointed out that for biofuel development, the elasticity of substitution between fossil fuels and feedstock in the petroleum industry is crucial, yet uncertain. The development of international trade and, therefore, for production and land use heavily depends on the value of the trade (Armington) elasticities. 
Table 4: Sensitivity analyses with regard to the elasticities in trade of and substitution between fossil and biofuels, 2020 relative to 2001

\begin{tabular}{|c|c|c|c|c|c|c|c|c|c|c|}
\hline & \multicolumn{2}{|c|}{ Standard } & \multicolumn{4}{|c|}{ Trade elasticities } & \multicolumn{4}{|c|}{ Substitution elasticities in petrol } \\
\hline & \multirow[t]{2}{*}{ Reference } & \multirow[t]{2}{*}{ BFD } & \multicolumn{2}{|c|}{ Reference } & \multicolumn{2}{|c|}{ BFD } & \multicolumn{2}{|c|}{ Reference } & \multicolumn{2}{|c|}{ BFD } \\
\hline & & & high & low & high & low & high & low & high & low \\
\hline \multicolumn{11}{|c|}{ Change in world price (\%), 2020 relative to 2001} \\
\hline Cereals & -12.6 & -7.1 & -13.4 & -11.5 & -9.1 & -4.7 & -11.4 & -14.2 & -6.8 & -8.5 \\
\hline Oilseed & -6.8 & 1.2 & -7.6 & -5.6 & -1.3 & 4.1 & -5.0 & -9.4 & 0.8 & 0.7 \\
\hline \multicolumn{11}{|c|}{ Share of biofuel crops in fuel consumption for transportation (\%), 2020 relative to 2001} \\
\hline Germany & 3.8 & 10.0 & 4.4 & 3.5 & 10.0 & 10.0 & 4.0 & 3.4 & 10.0 & 10.0 \\
\hline France & 1.8 & 10.0 & 2.0 & 1.6 & 10.0 & 10.0 & 2.2 & 1.4 & 10.0 & 10.0 \\
\hline Brazil & 30.8 & 29.6 & 30.3 & 31.6 & 29.3 & 30.3 & 32.0 & 29.2 & 30.6 & 28.5 \\
\hline NAFTA & 2.9 & 2.5 & 3.0 & 2.9 & 2.5 & 2.5 & 3.3 & 2.2 & 2.8 & 2.0 \\
\hline \multicolumn{11}{|c|}{ Change in oilseed production (\%), 2020 relative to 2001} \\
\hline Africa & 91.0 & 102.7 & 94.0 & 87.6 & 104.8 & 97.3 & 94.4 & 86.1 & 102.4 & 102.0 \\
\hline Asia & 61.4 & 63.7 & 58.1 & 65.9 & 61.2 & 67.8 & 62.2 & 59.6 & 64.0 & 63.8 \\
\hline C\&S America & 66.0 & 84.7 & 70.2 & 58.5 & 85.5 & 78.8 & 71.2 & 59.8 & 84.5 & 84.5 \\
\hline EU & 5.6 & 41.3 & 3.0 & 8.7 & 33.7 & 53.9 & 7.0 & 2.6 & 37.4 & 46.0 \\
\hline High income countries & 56.8 & 65.4 & 58.7 & 53.8 & 67.4 & 60.9 & 63.1 & 46.3 & 68.1 & 61.6 \\
\hline \multicolumn{11}{|c|}{ Change in agricultural land use (\%), 2020 relative to 2001} \\
\hline Africa & 36.2 & 36.6 & 36.4 & 36.0 & 36.9 & 36.4 & 36.3 & 36.2 & 36.8 & 36.7 \\
\hline Asia & 9.1 & 9.3 & 9.1 & 9.2 & 9.2 & 9.2 & 9.1 & 9.1 & 9.2 & 9.2 \\
\hline C\&S America & 35.5 & 38.5 & 35.9 & 34.8 & 38.9 & 37.8 & 36.1 & 34.9 & 39.0 & 38.4 \\
\hline EU & -8.8 & -4.9 & -9.1 & -8.5 & -6.5 & -2.6 & -8.6 & -9.1 & -5.3 & -4.9 \\
\hline High income countries & -0.5 & 0.5 & -0.7 & -0.2 & 0.1 & 0.5 & 0.0 & -1.1 & 0.5 & -0.1 \\
\hline \multicolumn{11}{|c|}{ Change in agricultural land use for biofuel crop production (in mio. ha) , 2020 relative to 2001} \\
\hline Africa & 1.6 & 3.1 & 2.6 & 0.5 & 3.8 & 1.9 & 2.1 & 0.8 & 3.1 & 2.9 \\
\hline Asia & 4.5 & 4.4 & 5.3 & 3.8 & 5.3 & 4.0 & 5.4 & 3.0 & 5.1 & 3.6 \\
\hline C\&S America & 6.1 & 22.7 & 4.0 & 5.7 & 23.0 & 19.6 & 9.4 & 3.2 & 24.2 & 20.7 \\
\hline EU & 1.4 & 12.8 & 1.6 & 1.4 & 11.6 & 14.4 & 2.0 & 0.7 & 12.4 & 12.8 \\
\hline High income countries & 20.2 & 22.9 & 21.6 & 19.0 & 23.5 & 21.3 & 26.2 & 11.2 & 26.4 & 18.3 \\
\hline \multicolumn{11}{|c|}{ Net-exports of biofuel crops, 2020 (in bill. constant 2001 US\$) } \\
\hline Africa & -1.1 & 1.8 & 0.0 & -2.4 & 3.0 & 0.0 & -0.6 & -1.7 & 2.3 & 1.1 \\
\hline Asia & -25.5 & -18.9 & -26.1 & -24.2 & -19.3 & -18.6 & -26.5 & -25.3 & -19.9 & $\begin{array}{r}18.6 \\
-18.6\end{array}$ \\
\hline C\&S America & 27.7 & 32.2 & 31.2 & 23.4 & 35.1 & 28.2 & 29.1 & 26.2 & 32.7 & 31.5 \\
\hline EU & -17.6 & -38.2 & -22.7 & -11.0 & -44.1 & -27.8 & -18.0 & -17.3 & -37.5 & -38.5 \\
\hline High income countries & 9.7 & 15.4 & 7.9 & 10.9 & 14.3 & 15.3 & 8.8 & 11.4 & 14.0 & 17.6 \\
\hline
\end{tabular}


The substitution elasticity between fossil fuels and biofuels describes the size of the change in input substitution given a change in the price of the inputs. The values applied in this analysis are based on Birur et al., (2007). Table 4 shows the results with elasticities of $50 \%$ above and $50 \%$ below the standard values. Under the assumptions of high elasticities, the relative price increase of fossil fuels to biofuels in the reference scenario induces greater replacement of fossil fuels with biofuels, implying higher biofuel shares, world crop prices, net-imports of biofuel crops and land use. Under the assumption of high substitution elasticities the net-exports of biofuel crops from North and South America strongly increases. The opposite is true in the case of low substitution elasticities. The height of the elasticities has a relatively large impact on variables directly involved in biofuel use and production such as biofuel input use, oilseed production, and oilseed world prices.

Table 4 shows that the results are also sensitive to the value of the so-called Armington trade elasticities. If the trade elasticities are higher, changes in international prices have a stronger impact on trade and domestic markets. Compared with the base scenario, the expansion of EU oilseed production is smaller if high trade elasticities are applied. On the other hand, with higher trade elasticities the use of biofuel crops becomes more profitable due to a greater decline in crop prices. As a consequence, the land used for biofuel crops in the EU expands, even while total agricultural area experiences a greater declines compared with the standard assumptions of the trade elasticities. If trade elasticities are assumed to be lower, domestic prices are higher relative to the standard assumption and fewer biofuel crops are used for fuel production. 


\section{Summary and conclusions}

This analysis shows that enhanced demand for biofuel crops under the EU Biofuel Directives has a strong impact on agriculture at both the global and the European levels. The long-term trend of declining real world prices of agricultural products slows down or reverses for the feedstock used for biofuels. The incentive to increase production in the EU will tend to increase land prices and farm income in the EU and other regions. The EU will not produce the feedstocks needed to generate the BFDprescribed biofuels domestically and will run into a higher agricultural trade deficit. Biofuel crop production and land use will expand in land-abundant countries-NAFTA and especially in South and Central America (e.g., Brazil)-due to increased exports to the EU. The resulting higher feedstock prices will reduce biofuel consumption outside the EU. However, at a global level the use of biofuels increases and crude oil demand decreases, leading to a decline in the world price of oil. The expansion of agricultural land use on a global scale, and especially in land-abundant South America, might indicate a decline in biodiversity, as land use is an important driver for biodiversity.

The results depend on the development of the crude oil price. The higher the crude oil price, the more competitive biofuel crops become in petroleum production; therefore, the share of biofuels in fuel consumption will increase endogenously, especially in Brazil, NAFTA, and the EU. Contrary to the EU Biofuel Directive, a higher oil price causes a biofuel crop trade deficit in NAFTA.

Without additional policies to stimulate the use of biofuel crops in the petroleum sector, such as mandatory blending, the targets of the EU Biofuel Directive will not be reached in 2010 or 2020. A mandatory blending policy leads to higher consumer prices for petrol, as agricultural feedstock are not profitable for use in fuel production given the current technologies. The increased demand for feedstock raises their price relative to the oil price and therefore adds to the challenge of making biofuels competitive.

The magnitude of the impacts depends on the substitutability of biofuels and crude oil and on the trade elasticities. Furthermore, all the results depend on the relative land availability of countries worldwide. Including a land supply curve is crucial if one studies the impacts of increased demand for biofuels on prices, trade, production, land use, and, ultimately, biodiversity.

Therefore, if biofuels must be competitive in the long run, investments in research and development are needed to obtain higher yields or better conversion technologies. However, in this paper the analysis focuses only on first generation biofuels. Decisions on research and development investments should account for the second generation biofuels, as these promise to be both better and more cost effective in reducing greenhouse gas emissions, although second generation biofuels will yield less by-products than first generation biofuels. 


\section{References}

Banse, M. and Grethe, H. (2008). Effects of the New Biofuel Directive on EU Land Use and Agricultural Markets. Paper presented on the 107th EAAE Seminar 'Modeling Agricultural and Rural Development Policies'. Seville (Spain).

Birur, D.K., Hertel, T.W. and Tyner, W.E. (2007). The Biofuel Boom: Implications for World Food Markets. Paper presented at the Food Economy Conference, The Hague, Netherlands.

Burniaux, J.M. and Truong, T.P. (2002). GTAP-E: An Energy-Environmental Version of the GTAP Model. GTAP Technical Paper, No. 16. Revised Version.

Cixous, A.C. (2006). Le Prix de la Terre dans les Pays Européens. Mémoire de Master - Recherche en Economie Internationale (2005/2006). Université Paris 1 Panthéon Sorbonne.

Convention on Biological Diversity CBD (2006). Global Biodiversity Outlook 2, Montreal.

CPB (2003). Four Futures of Europe, Netherlands Bureau for Economic Policy Analysis, the Hague, The Netherlands. See: http://www.cpb.nl

Dale, B.E. (2003). 'Greening' the Chemical Industry: Research and Development Priorities for Biobased Industrial Products, Journal of Chemical Technology and Biotechnology 78: 1093-1103.

De Janvry, A., Fafchamps, M. and Sadoulet, E. (1991). Peasant Household Behavior with Missing Markets: Some Paradoxes Explained. Economic Journal 101: 14001417.

Dixon, P. B., Osborne, S. and Rimmer, M. T. (2007). The Economy-Wide Effects in the United States of Replacing Crude Petroleum with Biomass. Paper presented at the GTAP Conference, Purdue University, Indiana, 2007.

Eickhout, B., Meijl, H. van, Tabeau, A. and Stehfest, E. (forthcoming). The Impact of Environmental and Climate Constraints on Global Food Supply. In Hertel, T., Rose, S. and Tol, R. (eds), Economic Analysis of Land Use in Global Climate Change Policy. (forthcoming).

Eickhout, B., Meijl, H. van, Tabeau, A. and Rheenen, R. van (2007). Economic and Ecological Consequences of four European Land Use Scenarios, Land Use Policy 24: $562-575$. 
Eickhout, B. and A.G. Prins, 2008. Eururalis 2.0 Technical background and indicator documentation. Wageningen UR and Netherlands Environmental Assessment Agency (MNP) Bilthoven, The Netherlands.

Elobeid, A. and Tokgoz, S. (2006). Removal of U.S. Ethanol Domestic and Trade Distortions: Impact on U.S. and Brazilian Ethanol Markets. Working Paper 06-WP 427. Center for Agricultural and Rural Development. Iowa State University. Ames.

European Commission (2003). Directive 2003/30/EC on the Promotion of the Use of Biofuels or Other Renewable Fuels for Transport. OJ L 123, 17.5.2003. Brussels.

European Commission (2007a). Biofuels Progress Report. Report on the Progress Made in the Use of Biofuels and Other Renewable Fuels in the Member States of the European Union. Brussels.

European Commission (2007b). The Impact of a Minimum 10\% Obligation for Biofuel Use in the EU-27 in 2020 on Agricultural Markets. Impact Assessment of the Renewable Energy Roadmap - March 2007. DG AGRI. Directorate G. Economic Analysis, Perspectives and Evaluations. G.2. Economic Analysis of EU Agriculture. Brussels.

European Commission (2008). 2020 by 2020. Europe's climate change opportunity Communication from the Commission to the European Parliament, the Council, the European Economic and Social Committee and the Committee of the Regions. $\operatorname{COM}(2008) 30$ final. 23.01.2008. Brussels.

F.O. Licht (2007). Licht Interactive Data.

Gohin, A., and Moschini, G. (2007). Impacts of the European Biofuel Policy on the Farm Sector: A General Equilibrium Assessment. Paper presented on the 'Biofuels, Food \& Feed Tradeoffs' Conference organized by Farm Foundation and the USDA, St. Louis, Missouri

Hertel, T. (1997). Global Trade Analysis. Modelling and Applications, Cambridge University Press.

Hertel, T., Rose, S. and Tol, R. (eds.) (forthcoming). Economic Analysis of Land Use in Global Climate Change Policy, Publisher: Routledge.

Hertel, T.W., Anderson, K., Hoekman, B., Francois, J.F. and Martin, W. (2004). Agriculture and Non-agricultural Liberalization in the Millennium Round. In: Ingco, M.D. and Winters, L.A. (eds.). Agriculture and the New Trade Agenda. Cambridge University Press, Cambridge and New York (Chapter 11).

Hoogwijk M, Faaij, A., Eickhout, B., Vries, B. de and Turkenburg, W. (2005). Potential Biomass Energy out to 2100 for Four IPCC SRES Land-use Scenarios. Biomass and Bioenergy 29: 225-257.

Huang, H., Tongeren, F. van, Dewbre, F. and Meijl, H. van (2004). A New Representation of Agricultural Production Technology in GTAP. Paper presented at 
the Seventh Annual Conference on Global Economic Analysis, June, Washington, USA.

Keeney, R. and Hertel, T. (2005). GTAP-AGR: A Framework for Assessing the Implications of Multilateral Changes in Agricultural Policies. GTAP Technical Paper No.24. August, 2005.

Lampe, M. von (2007). Economics and Agricultural Market Impacts of Growing Biofuel Production. Agrarwirtschaft 55: 232-237.

Lee, H.-L., Hertel, T. W., Sohngen, B. and Ramankutty, N. (2005). Towards and Integrated Land Use Data Base for Assessing the Potential for Greenhouse Gas Mitigation. GTAP Technical Paper No. 25, Center for Global Trade Analysis, Purdue University.

McDonald, S., Robinson, S. and Thierfelder, K. (2006). Impact of Switching Production to Bioenergy Crops: The Switchgrass Example. Energy Economics 28: 243-265.

Meijl, H. van and Tongeren, F. van (2002). The Agenda 2000 CAP Reform, World Prices and GATT-WTO Export Constraints. European Review of Agricultural Economics 29: 445-470.

Meijl, H. van, Rheenen, T. van, Tabeau, A. and Eickhout, B. (2006). The Impact of Different Policy Environments on Land Use in Europe. Agriculture, Ecosystems and Environment 114: 21-38.

Nakicenovic, N. and Swart R. (eds) (2000). Special Report on Emission Scenarios. Intergovernmental Panel on Climate Change (IPCC), Geneva, Switzerland.

Nowicki, P., Meijl, H. van, Knierim, A., Banse, M., Helming, J., Margraf, O., Matzdorf, B., Mnatsakanian, R., Reutter, M., Terluin, I., Overmars, K., Verhoog, D., Weeger, C. and Westhoek, H. (2007). Scenar 2020 - Scenario Study on Agriculture and the Rural World. European Commission, Directorate-General Agriculture and Rural Development, Brussels.

OECD (2003). Agricultural Policies in OECD Countries 2000. Monitoring and Evaluation. Organization for Economic Co-operation and Development, Paris.

OECD (2006). Agricultural Market Impact of Future Growth in the Production of Biofuels. OECD, Paris, France.

Rajagopal, D and Zilberman, D. (2007). Review of Environmental, Economic and Policy Aspects of Biofuels. Policy Research Working Paper 4341. World Bank.

Reilly, J. and Paltsev, S. (2007). Biomass Energy and Competition for Land, Report of MIT. Joint Program on the Science and Policy of Global Change, No. 145. 
Rienks, W.A. (ed), 2008, The future of rural Europe. An Antology based on the results of EUruralis 2.0 scenario study, Wageningen University and Research Center and Netherlands Environmental Planing Agency (MNP). http://www.eururalis.eu.

Rosegrant, M.W., Zhu, T., Msangi, S. and Sulser, T. (2007). Global Scenarios for Biofuels: Impacts and Implications, IFPRI.

Sadoulet, E., and Janvry, A. de (1995). Quantitative Development Policy Analysis. Baltimore, Maryland: The Johns Hopkins University Press.

Schmidhuber, J. (2006). The Nutrition and the Energy Transition of World Agricultural Markets. In Bahrs, E., Cramon-Taubadel, S. von, Spiller, A., Theuvsen L. and Zeller, M. (eds), Unternehmen im Agrarbereich vor neuen Herausforderungen. Münster-Hiltrup: Landwirtschaftsverlag, 9-30.

Schmidhuber, J. (2007). Biofuels: An Emerging Threat to Europe's Food Security? Impact of an Increased Biomass Use on Agricultural Markets, Prices and Food Security: A Longer-term Perspective, www.notre-europe.eu.

Smeets, E., Faaij, A., Lewandowski, I. and Turkenburg, W. (2006). A Bottom up Quickscan and Review of Global Bio-energy Potentials to 2050, Progression in Energy and Combustion Science 33: 56-106.

Tokgoz, S., Elobeid, A., Fabiosa, J., Hayes, D.J., Babcock, B.A., Hart, C. E., Beghin, J.C., Yu, T.H. and Dong, F. (2007). Emerging Biofuels: Outlook of Effects on U.S. Grain, Oilseed, and Livestock Markets. CARD Staff Report 07-SR 101. Center for Agricultural and rural Development, Iowa State University.

Tyner, W.E., Dooley, F., Hurt, Ch. and Quear, J. (2008). Ethanol Pricing Issues for 2008. Purdue University.

US Energy Information Administration (2008). U.S. Energy Consumption by Fuel (1980-2030). http://www.eia.doe.gov/oiaf/forecasting.html. Download: 06/02/2008.

Varian, H.R. (2003). Intermediate Microeconomics. A Modern Approach. $6^{\text {th }}$ Edition. New York.

Wageningen UR and Netherlands Environmental Assessment Agency (2007). Eururalis 2.0. A Scenario Study on Europe's Rural Areas to Support Policy Discussion.

Wiesenthal, T., Leduc, G., Christidis, P., Pelkmans, L. and Georgopo, P. (2007). Assessment of Biofuel Policies in Europe - Lessons Learnt and Future Policy Options. Policy-Synthesis of the Premia Project. 


\section{Annex}

Table A1: Region aggregation

\begin{tabular}{|c|c|}
\hline Regions & Original GTAP v 6 regions \\
\hline $\begin{array}{l}\text { Belgium, } \\
\text { Luxembourg }\end{array}$ & Belgium, Luxembourg \\
\hline Denmark & Denmark \\
\hline Germany & Germany \\
\hline Greece & Greece \\
\hline Spain & Spain \\
\hline France & France \\
\hline Ireland & Ireland \\
\hline Italy & Italy \\
\hline Netherlands & Netherlands \\
\hline Austria & Austria \\
\hline Portugal & Portugal \\
\hline Finland & Finland \\
\hline Sweden & Sweden \\
\hline UK & United Kingdom \\
\hline Baltic countries & Estonia, Latvia, Lithuania \\
\hline Cyprus, Malta & Cyprus, Malta \\
\hline Czech Republic & Czech Republic \\
\hline Hungary & Hungary \\
\hline Poland & Poland \\
\hline Slovenia & Slovenia \\
\hline Slovakia & Slovakia \\
\hline Bulgaria, Romania & Bulgaria, Romania \\
\hline Rest of Europe & Switzerland, Rest of EFTA, Rest of Europe, Albania, Croatia \\
\hline $\begin{array}{l}\text { Former Soviet } \\
\text { Union }\end{array}$ & Russian Federation, Rest of Former Soviet Union \\
\hline Turkey & Turkey \\
\hline $\begin{array}{l}\text { Rest of Middle } \\
\text { East }\end{array}$ & Rest of Middle East \\
\hline NAFTA & United States, Canada, Mexico \\
\hline Brazil & Brazil \\
\hline Rest of America & $\begin{array}{l}\text { Rest of North America, Colombia, Peru, Venezuela, Rest of Andean Pact, } \\
\text { Argentina, Chile, Uruguay, Rest of South America, Central America, Rest } \\
\text { of FTAA, Rest of the Caribbean }\end{array}$ \\
\hline Oceania & Australia, New Zealand, Rest of Oceania \\
\hline Japan, Korea & Japan, Korea \\
\hline East Asia & China, Hong Kong, Taiwan, Rest of East Asia \\
\hline Rest of Asia & $\begin{array}{l}\text { Indonesia, Malaysia, Philippines, Singapore, Thailand, Vietnam, Rest of } \\
\text { Southeast Asia, Bangladesh, India, Sri Lanka, Rest of South Asia, Canada }\end{array}$ \\
\hline North Africa & Morocco, Rest of North Africa \\
\hline $\begin{array}{l}\text { Sub-Saharan } \\
\text { Africa }\end{array}$ & $\begin{array}{l}\text { Botswana, Rest of South African CU, Malawi, Mozambique, Tanzania, } \\
\text { Zambia, Zimbabwe, Rest of SADC, Madagascar, Uganda, Rest of Sub- } \\
\text { Saharan Africa }\end{array}$ \\
\hline
\end{tabular}


Table A2: Sector aggregation

\begin{tabular}{|c|c|}
\hline $\begin{array}{l}\text { Sectors in } \\
\text { GTAP }\end{array}$ & Original GTAP v 6 sectors \\
\hline Rice & Paddy and processed rice \\
\hline Wheat & Wheat \\
\hline Grain & Cereal grains nec. \\
\hline Oilseeds & Oil seeds \\
\hline $\begin{array}{l}\text { Sugar } \\
\text { canelbeet }\end{array}$ & Sugar cane, sugar beet \\
\hline Horticulture & Vegetables, fruit, nuts \\
\hline Other crops & Plant-based fibers; crops nec. \\
\hline Cattle & $\begin{array}{l}\text { Cattle, sheep, goats, horses; wool, silk-worm cocoons; meat: cattle, sheep, goats, } \\
\text { horse }\end{array}$ \\
\hline $\begin{array}{l}\text { Other animal } \\
\text { products }\end{array}$ & Animal products nec.; meat products nec. \\
\hline Milk & Raw milk \\
\hline Dairy & Dairy products \\
\hline Sugar & Sugar \\
\hline Vegetable oils & Vegetable oils and fats \\
\hline Other food & Food products nec. \\
\hline Other Agro & Fishing; beverages and tobacco products \\
\hline Forestry & Forestry \\
\hline Oil & Crude oil \\
\hline Petroleum & Petroleum, coal products \\
\hline Gas & Gas; Gas manufacture, distribution \\
\hline Coal & Coal \\
\hline Electricity & Electricity \\
\hline Industries & $\begin{array}{l}\text { Minerals nec.; textiles; wearing apparel; leather products; wood products; paper } \\
\text { products, publishing; chemical, rubber, plastic prods; mineral products nec.; } \\
\text { ferrous metals; metals nec.; metal products; motor vehicles and parts; transport } \\
\text { equipment nec.; electronic equipment; machinery and equipment nec.; } \\
\text { manufactures nec. }\end{array}$ \\
\hline Services & $\begin{array}{l}\text { Water; construction; trade; transport nec.; sea transport; air transport; } \\
\text { communication; financial services nec.; insurance; business services nec.; } \\
\text { recreation and other services; public administration, defense, health, education; } \\
\text { dwellings }\end{array}$ \\
\hline
\end{tabular}


Table A3: Annual Percent Change in Total GDP, 2001-2020

\begin{tabular}{|c|c|c|c|c|}
\hline & Reference & BFD & $\begin{array}{l}\text { Reference, high } \\
\text { oil price }\end{array}$ & $\begin{array}{c}\text { BFD, } \\
\text { high oil price }\end{array}$ \\
\hline Belgium, Luxembourg & 2.52 & 2.52 & 2.51 & 2.50 \\
\hline Denmark & 2.77 & 2.77 & 2.75 & 2.75 \\
\hline Germany & 2.17 & 2.18 & 2.16 & 2.16 \\
\hline Greece & 2.75 & 2.76 & 2.74 & 2.73 \\
\hline Spain & 3.26 & 3.26 & 3.25 & 3.24 \\
\hline France & 2.69 & 2.70 & 2.68 & 2.68 \\
\hline Ireland & 3.29 & 3.29 & 3.28 & 3.27 \\
\hline Italy & 2.12 & 2.13 & 2.11 & 2.11 \\
\hline Netherlands & 2.71 & 2.71 & 2.70 & 2.69 \\
\hline Austria & 2.63 & 2.63 & 2.62 & 2.61 \\
\hline Portugal & 2.72 & 2.72 & 2.70 & 2.70 \\
\hline Finland & 2.73 & 2.73 & 2.72 & 2.71 \\
\hline Sweden & 2.75 & 2.76 & 2.74 & 2.74 \\
\hline UK & 2.50 & 2.50 & 2.49 & 2.48 \\
\hline Baltic countries & 4.19 & 4.21 & 4.20 & 4.19 \\
\hline Cyprus, Malta & 3.16 & 3.16 & 3.16 & 3.15 \\
\hline Czech Republic & 3.47 & 3.47 & 3.46 & 3.46 \\
\hline Hungary & 3.36 & 3.36 & 3.36 & 3.35 \\
\hline Poland & 3.86 & 3.87 & 3.86 & 3.85 \\
\hline Slovenia & 2.65 & 2.65 & 2.65 & 2.64 \\
\hline Slovakia & 4.22 & 4.23 & 4.22 & 4.21 \\
\hline Bulgaria, Romania & 6.00 & 6.00 & 6.00 & 6.00 \\
\hline Rest of Europe & 2.75 & 2.75 & 2.71 & 2.71 \\
\hline Former Soviet Union & 4.22 & 4.22 & 4.14 & 4.14 \\
\hline Turkey & 5.14 & 5.16 & 5.13 & 5.13 \\
\hline Rest of Middle East & 4.09 & 4.09 & 3.92 & 3.92 \\
\hline NAFTA & 2.85 & 2.85 & 2.85 & 2.85 \\
\hline Brazil & 3.64 & 3.64 & 3.62 & 3.63 \\
\hline Rest of America & 3.74 & 3.74 & 3.71 & 3.71 \\
\hline Oceania & 2.44 & 2.44 & 2.43 & 2.43 \\
\hline Japan, Korea & 1.72 & 1.72 & 1.72 & 1.72 \\
\hline East Asia & 6.40 & 6.40 & 6.39 & 6.39 \\
\hline Rest of Asia & 5.12 & 5.12 & 5.11 & 5.11 \\
\hline North Africa & 4.88 & 4.88 & 4.83 & 4.83 \\
\hline Sub-Saharan Africa & 5.57 & 5.57 & 5.47 & 5.47 \\
\hline South Africa & 4.57 & 4.57 & 4.56 & 4.56 \\
\hline
\end{tabular}




\section{Abbreviations and definition of terms}

bbl: barrel

Biomass: Plant matter that can be used as fuel or for other commercial and industrial uses. The source of biomass can either be purpose-grown crops or crop wastes and residues, which are generated by agricultural or forestry activities.

Bioenergy: Energy derived from biomass.

Biofuel: Fuels derived from biomass, which can be in solid, liquid, or gaseous states. In the context of this paper, it is taken to refer to liquid transportation fuel derived from biomass.

BFD-5.75\%: Biofuel directive of 5.75\% obligatory blending in the EU.

BFD-10\%: Biofuel directive of 10\% obligatory blending in the EU.

CGE: Computable General Equilibrium Model

CES: Constant Elasticity of Substitution

CET: Constant Elasticity of Transformation

COP: Cereals, Oilseeds, and Protein crops

CPB: Netherlands Bureau of Economic Policy Analysis

C\&S Amer: Central and South America

EU: European Union

EU15: Countries that were EU members prior to 2005 enlargement (Belgium, Luxembourg, Denmark, Germany, Greece, Spain, France, Ireland, Italy, Netherlands, Austria, Portugal, Finland, Sweden, United Kingdom).

EU12: 12 member states that joined the EU in 2005 and 2007 (Estonia, Latvia, Lithuania, Cyprus, Malta, Czech Republic, Hungary, Poland, Slovenia, Slovakia, Bulgaria, Romania).

FCP: Field Crops and Pasture

Fossil energy: Energy derived from sources like coal and petroleum (crude oil and natural gas), which are formed from the fossilized remains of dead plants and animals over millions of years.

GTAP: Global Trade Analyses Project. A consortium that provides data and a standard general equilibrium model. 
GTAP-E: GTAP energy model

HighInc: High Income countries (Japan and Korea, Oceania)

IMAGE: Integrated Model to Assess the Global Environment

NAFTA: North American Free Trade Agreement countries (USA, Canada, and Mexico)

PEM: Policy Evaluation Matrix (OECD)

Renewable energy: Energy derived from resources that either cannot be depleted or can be regenerated.

TFP: Total Factor Productivity Growth 